\title{
Political Information Flow and Management Guidance*
}

\begin{abstract}
We examine whether politically active firms play a role in disseminating political information via their management guidance. Using campaign financing activity or the presence of a government affairs office to proxy for firms' access to political information, we find that politically active firms are more likely to issue management guidance overall, and especially when the government is a customer of the firm. Further, relative to politically inactive firms, the guidance released by politically active firms is more likely to discuss government policies. In addition to using numerous econometric techniques to address self-selection, we examine the timing of when guidance is issued. We find that politically active firms are more likely to issue guidance and change their government policy-related disclosures prior to the public revelation of government policy decisions. Collectively, these findings suggest that the privileged information firms obtain through their political activities is shared with investors through voluntary disclosures.
\end{abstract}

Keywords: Political connections; Information flow; Management forecasts; Corporate disclosure JEL Classification: D82, D83, G38, G14, M41 


\section{Introduction}

A recent line of research investigates the role of differential access to material nonpublic information from policymakers in securities markets (e.g., Gao and Huang 2016; Christensen et al. 2017). Privileged access to the strategic details of upcoming hearings, current policy positions, and any potential amendments that others might offer (i.e., political information) is made possible because members of Congress are legally permitted to selectively disclose such information to outside parties (see, e.g., Jerke 2010; Bainbridge 2012; Nagy and Painter 2012; Wright 1996). Initially, provisions that would have required mandatory disclosure around the flow of political information were included in the Stop Trading on Congressional Knowledge (STOCK) Act, which passed in April 2012, but these provisions were removed prior to the final vote on the bill. A subsequent bill was later introduced aimed at addressing the lack of transparency around the flow of political information (Political Intelligence Transparency Act of 2017), but was not enacted, in part due to lack of evidence on how political information is disseminated, to whom, and for what purpose. Our paper aims to provide insights on whether firms with differential access to political information (i.e., politically active firms) have a role in voluntarily disseminating this information. Specifically, we investigate the impact of access to political information on voluntary disclosure by examining whether access to political information influences the provision and content of management guidance.

Politically active firms' information advantage may influence the provision and content of their guidance because it improves firms' ability to assess the impact of expected political outcomes on firm performance. Consistent with the notion that politically active firms have better information about expected political outcomes relative to inactive firms (Bremmer 2005), prior research demonstrates that access to institutional details throughout the legislative and 
regulatory process leads to more informed investment decisions (Wellman 2017; Ovtchinnikov et. al. 2019). Under this mechanism, access to private political information increases the quality of managers' information about the potential impact of various policy alternatives, thereby reducing the costs associated with communicating those expectations to investors (see Verrecchia 1990). Thus, we predict that managers at politically active firms are more likely to issue management guidance and discuss government policy relative to managers at inactive firms.

Even if access to political information improves firms' ability to anticipate and analyze the impact of various policy alternatives, there are several reasons that managers may be reluctant to convey this information to investors. First, if expected political outcomes are unfavorable for the firm, managers may be reluctant to issue "bad news" guidance (e.g., Beyer et al. 2010). Second, even if managers expect favorable policy developments, they may incur proprietary costs. That is, firms may be reluctant to disclose political information because it also reveals a competitive advantage that politically active firms have over their inactive industry peers (Ferracuti et al. 2019). ${ }^{1}$ Relatedly, firms with political connections may face lower capital market incentives and/or litigation risk, making it less likely to voluntarily disclose information (Hung et al. 2018). Finally, the source of the political information (e.g., members of Congress) may prefer that firms not disclose privileged information to the market, as doing so may damage the relationship between the firm and the politician. Thus, whether access to political information affects voluntary disclosure is an empirical question.

To investigate this issue, we test whether the propensity to provide management guidance is associated with firms' access to political information. We examine two proxies for firms' access to this information based on their political activism. Our first proxy relies on arguments in

\footnotetext{
${ }^{1}$ See, for example, Bamber and Cheon (1998), Verrecchia and Weber (2006), Cao, Ma, Tucker and Wan (2018).
} 
prior literature that political connections formed through campaign-financing activity serve as the most observable proxy for access to politicians and political information (e.g., Christensen et al. 2017; Hojnacki and Kimball 2001; Humphries 1991). Thus, we use political connection measures from Cooper et al. (2010), which are based on contributions from firms' political action committees (PACs), as our first proxy for access to political information. Our second proxy is the existence of a government relations office at a firm. Firms' government relations offices act as a central resource for analyzing the likelihood of policy change and the potential impact on the firm (Bremmer 2005). A key input into legislators' policy decisions is the policy research provided by politically active firms regarding the economic viability of proposed legislation (Wright 1996). By supplying this information to legislators, politically active firms reinforce ongoing access to policymakers and thus political information (Hillman and Hitt 1999). Using these measures, we estimate that managers of politically active firms are between 5 and 7 percentage points more likely to issue earnings guidance than their inactive peers, after controlling for other known firm characteristics identified in the prior literature as influencing disclosure policy. Moreover, we find that this difference in the propensity to guide is especially pronounced for firms with greater sensitivity to government actions, as measured by having the government as a major customer.

If access to political information induces firms to issue guidance, then we also expect politically active firms to mention government policy-related terms more frequently in their guidance. To test this prediction, we measure the frequency of government policy-related terms that appear in firms' guidance disclosures obtained from 8-K filings. Using the policy dictionaries developed by Baker et al. (2016) that cover topics such as government spending, 
national defense, healthcare, trade, and fiscal and monetary policy to measure the frequency of policy-related terms, we find evidence consistent with this prediction.

Since the choice to become politically active is endogenous, a concern is that our findings are driven by this self-selection. To address this concern, we employ various econometric techniques, including entropy matching, instrumental variables (where the distance of the firm's headquarters from Washington D.C. is our instrument), firm fixed effects, and an analysis of selection on unobservables, to address the influence of both observable and unobservable characteristics on our inferences. Our findings are robust to these econometric techniques.

Overall, our results are consistent with politically active firms having differential access to political information and voluntarily disclosing this information to their investors. However it is also possible that politically active firms may simply have heightened exposure to political outcomes, and thus are more likely to increase the provision of guidance and discuss government policies more to alleviate investor uncertainty, even without differential access to political information (Anantharaman and Zhang 2011; Balakrishnan, Billings, Kelly, and Ljungvist 2014; Billings, Jennings, and Lev 2015; Guay, Samuels and Taylor 2016; Hassan et al. 2019; Nagar et al. 2019; Verrecchia 1990). ${ }^{2}$ To assess whether this second explanation explains our results, we control for the firm's sensitivity to economic policy uncertainty and find that our results hold, suggesting that investor demand for information about politically sensitive firms is not the sole reason for the increased propensity to disclose.

To further distinguish between these two explanations, we study the timing and content of management guidance relative to legislation that will impact the firm. These analyses mitigate differences in government policy sensitivity across firms by including only those firms that

\footnotetext{
${ }^{2}$ For evidence on investor uncertainty stemming from governmental actions, see Pástor and Veronesi (2012, 2013), Kelly, Pástor and Veronesi (2016), and Baker, Bloom, and Davis (2016).
} 
either directly lobbied for the legislation or are product-market peers to lobbying firms (see Section 5.3 for more detail). If politically active firms have differential access to political information and have incentives to voluntary disclose this information through guidance, we expect politically active firms to strategically release guidance before uncertainty about legislative action is resolved (i.e., when their information advantage is greatest). Consistent with this prediction, we find that politically active firms are more likely to issue guidance in the preenactment period. In contrast, politically inactive firms experience an increase in the incidence of guidance during the post-enactment period. Together, this evidence suggests that both politically active and inactive firms are sensitive to newly enacted legislation (i.e., both groups of firms respond to legislative changes by issuing guidance), but politically active firms are able to issue guidance during a window that is consistent with differential access to political information (i.e., during the pre-enactment window). Moreover, if access to private information is inducing the decision to disclose, we expect that the content of guidance ahead of legislative decisions (i.e., when the firm is more likely to have political information) to be different than guidance issued during periods when the firm is less likely to have political information (i.e., around the earnings announcement). Our results are consistent with this prediction. Specifically, using firms' own guidance at the prior earnings announcement as a benchmark, we find that immediately prior to legislative votes politically active firms change the policy-related language in their guidance more than politically inactive firms. Collectively, these additional tests provide further support for our conclusion that observed differences in management guidance by politically active firms are influenced by differential access to political information.

Our work contributes to the ongoing policy debate concerning regulation over the flow of political information. While the STOCK Act prohibits insider trading by members of Congress, 
this Act did not restrict Congress members from disclosing material non-public political information to constituents, despite concerns that this practice leads to an unfair advantage to those with access. Prior research provides support for this unfair advantage by documenting that sophisticated investors with access to political information amass greater trading profits (Gao and Huang 2016; Jagolinzer et al. 2018). Our findings suggest that management guidance is one channel through which the market can learn about the expected impact of policy developments, potentially mitigating concerns of an unfair advantage.

Our findings also contribute to the literature that investigates incentives to provide voluntary disclosure. Extant disclosure models suggest managers will respond to greater uncertainty about firm value by providing more voluntary disclosure (e.g., Verrecchia 1990). Consistent with this theoretical prediction, a growing empirical literature finds that firms respond to deterioration in the information environment by providing greater voluntary disclosure (e.g., Balakrishnan et al. 2014; Guay et al. 2016). Recent research documents an increase in the provision of guidance in response to market-wide political uncertainty in general (Nagar et al. 2019), and around monetary policy announcements, specifically (Choi et al. 2019). Furthermore, Hassan et al. (2019) find that firms with greater exposure to economic policy uncertainty devote a larger share of their quarterly conference calls to discussing political risk. Taken together, these papers suggest an association between aspects of political uncertainty and voluntary disclosure. However, they do not provide evidence on whether firms have differential access to private political information and if so, the mechanism through which firms can gain access to political information. Further, these studies do not investigate whether politically active firms choose to voluntarily disclose this information to their investors or provide evidence of policy-related discussion in firms' guidance, which we provide. 
In a recent study, Hung et al. (2018) examine the association between political connections and voluntary disclosure in an international setting. Using data from 2002 to 2004 with political connections primarily from Southeast Asia, they document that firms with a large shareholder or top director that is a minister or head of state, a member of parliament, or closely related to a top official issue fewer voluntary disclosures. They interpret their findings as suggesting that these firms face lower incentives to issue voluntary disclosures because their political connections afford them with better access to capital and loan terms and protection from litigation. By contrast, we focus on the U.S. setting and examine the role of political activism to gain access to political information. In our setting, over the years 2001 to 2014 we show that firms with greater access to political information are more likely to issue guidance, discuss government policy more, and time guidance around political events. Taken together, our results along with Hung et al. suggest that the regulatory and institutional environment influences the extent to which politically active firms serve as a conduit through which political information flows to the market.

This paper proceeds as follows. In Section 2, we provide background on the institutional details of political information. In Section 3, we discuss the empirical measures for our key constructs: a firm's access to political information, policy-related disclosures, and a firm's sensitivity to policy changes. Section 4 first describes our sample and then provides the results of our main tests for the association between political activity and the likelihood and content of guidance. Section 5 provides additional tests to disentangle alternative explanations for our findings. Section 6 concludes. 


\section{Background on Political Information}

When evaluating the efficacy of various policy alternatives, policymakers face uncertainty over how their constituents will react to or be affected by their policy decisions, as well as the political viability of various proposals. To reduce uncertainty, legislators will invite groups and individuals to provide information on the expected consequences of policy decisions. In communicating with their constituents, policymakers also reveal institutional details, such as procedural strategies that committee members will employ in markup sessions, positions that legislators have taken or are thinking about taking, and amendments that other legislators or outside groups might suggest (Wright 1996). Access to this type of information, which we (and prior literature) refer to as political information, can be useful in variety of settings.

A growing body of research investigates the role of differential access to political information in securities markets. Gao and Huang (2016) find that hedge funds with lobbyist ties earn abnormal profits on policy-sensitive stocks. Christensen et al. (2017) find that analyst recommendations issued by politically connected brokerage houses are more profitable than those of non-connected brokers. The evidence in Jagolinzer et al. (2018) suggests that access to politicians increases managers' and directors' trading profits. These studies provide evidence of unintended consequences associated with politicians' selective disclosure of material, nonpublic information in the form of benefits obtained by sophisticated market participants.

To capitalize on these benefits, an entire industry has developed recently around the practice of gathering and disseminating nonpublic political information to select outside parties. ${ }^{3}$ The recent emergence of the political intelligence industry is drawing the attention of lawakers who publicly question the industry practice of gathering political information for well-paying clients, but at the same time are reluctant to take steps toward regulating the industry without a

\footnotetext{
${ }^{3}$ Jerke (2010) and Nagy and Painter (2012) provide institutional details on the political intelligence industry.
} 
better understanding of how political information is disiminated and the potential consequences associated with differential information flow (Heltman 2015, Mullins 2012 a,b; 2014). While third-party consultants and sophisticated traders are the focus of media attention, some corporate players are bringing the practice of collecting and analyzing political inteligence in-house through a government relations office (Bremmer 2005).

Consistent with the ability of politically active firms to access and rely on political information, additional studies explore the role of political information for firms' corporate decisions. Ovtchinnikov et al. (2019) document evidence consistent with politically active firms innovating more (i.e., through developing and/or acquiring well cited patents). Moreover, the authors analyze investments in patent technology around industry de-regulation and document that politically active firms have an advantage over inactive firms stemming from their ability to anticipate regulatory developments. Wellman (2017) analyzes differences in the timing of capital investments between politically active and inactive firms around the Jobs and Growth Tax Reconciliation and Relief Act (JGTRRA). She demonstrates that politically active firms seem to anticipate the passage of JGTRRA, delaying investments relatively more in the pre-enactment period in order to of take advantage of lucrative tax incentives in the post-enactment period. Collectively, these studies support the notion that managers of politically active firms access and rely on political information when making investment decisions.

To the extent managers have incentives to communicate political information (e.g., the expected impact of policy developments) to their investors, we expect that managers at politically active firms are more likely to issue management guidance relative to managers at inactive firms. Building on theory and evidence that suggests managers are motivated to reduce investor uncertainty by providing more voluntary disclosure, Nagar et al. 2019 document an 
increase in the average level of management guidance in response to market-wide policy uncertainty, which partially mitigates the negative effect of policy uncertainty on investor information asymmetry. Moreover, Choi et al. (2019) document management guidance in advance of monetary policy news assists in reducing investor uncertainty.

While prior research investigates time-series variation in the provision of guidance conditional on general policy uncertainty and investors' reliance on guidance during high policy uncertainty periods, we are, by contrast, interested in the potential information flows to managers and capital market participants that stem from firms' differential access to policy news. As such, we examine the incidence, content, and timing of voluntary guidance firms provide to the market. By doing so, we examine whether there is evidence consistent with managers not only gaining access to political information, but also sharing that information with the capital markets. In the next section, we discuss our empirical strategy for investigating our research questions.

\section{Data and Measurement}

In this section, we outline our approach for measuring firms' access to political information. Since the decision to issue management guidance and the decision to invest in political access are not exogenously determined, we ensure that our results hold after employing several tests to address correlated omitted variables and endogeneity (see Section 5).

\subsection{Access to Political Information}

Our measures for political activity are intended to capture firms' access to legislators because access should facilitate information flow between firms and legislators. Consistent with this conjecture, most scholars agree that political connections formed through campaignfinancing activity serve as the most observable proxy for access (e.g., Schuller et al. 2002; 
Hojnacki and Kimball 2001; Wright 1996; Humphries 1991). Firms' campaign-financing activity (or lack thereof) is observable because of the Federal Election Committee (FEC) requirements to disclose campaign contributions. Although the Federal Election Campaign Act prohibits corporations from making contributions directly to federal elections campaigns, corporations may legally participate in federal election activities through a corporate sponsored Political Action Committee (PAC). For example, the corporate sponsored PAC can solicit contributions from the corporation's executives, employees, and stockholders. Corporate executives managing the PAC then strategically allocate these funds to political campaigns. ${ }^{4}$ These contributions (i.e., hard money contributions) are summarized and reported to the FEC on an interim basis. Unfortunately, other forms of campaign support (such as helping candidates with fundraising, PAC operating expenses, and independent expenditures) do not require disclosure. To the extent that corporations rely on multiple political tactics in order to accomplish their objectives, measures based on disclosed contributions may be incomplete. However, as Cooper et al. (2010) discuss, regardless of how political connections are formed, as long as campaign contributions disclosed to the FEC are correlated with other ways that political connections are created and maintained, the measures we use should serve as reasonable proxies for access to political information. ${ }^{5}$

Thus, our first two proxies for firms' access to political information is based on firms' campaign financing activities as reported to the FEC. The first, CONNECTED, is an indicator

\footnotetext{
${ }^{4}$ There are limits imposed on both the amount of money a PAC can solicit and the amount of money that a PAC can contribute to a federal election. For example, individuals can contribute up to $\$ 5,000$ per year per corporate sponsored PAC. Contributions from the corporate sponsored PAC to candidate campaigns are limited to $\$ 5,000$ per candidate per election. The limits on contributions to House and Senate candidates apply separately to each election in which a candidate participates. In House and Senate races, each primary election, general election, runoff, and special election is considered a separate election. There are no limits, however, on PAC "operating costs," which includes fundraising activities and electioneering campaigns.

${ }^{5}$ Prior literature maintains that less observable political strategies are a complementary to investments in campaign financing (Schuler et al. 2002). However, to the extent that other indirect sources serve as a substitute mechanism for obtaining political information, it would bias us against finding our predicted results.
} 
variable that equals one if the firm makes any PAC contributions during the year, zero otherwise (Christensen et al. 2017). This simple dichotomous variable, while useful for assessing economic magnitudes, does not consider the degree of political contributions, nor the multi-period nature

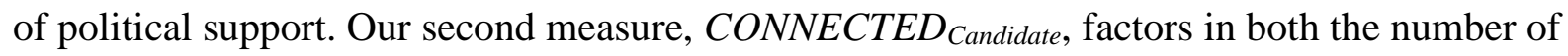
politicians the firm supports, and also uses a longer window to measure political connections. As a consequence, this measure may better capture the number of channels through which information can flow. Specifically, following Cooper et al. (2010), it is defined as:

$$
\text { CONNECTED } D_{\text {Candidate }, i}=\operatorname{Ln}\left(1+\sum_{p=1}^{J} \operatorname{Cand}_{p t, t-5}\right)
$$

where $\operatorname{Cand}_{p t, t-5}$ is an indicator variable equal to one if firm $i$ has contributed money to candidate $p$ over the years $t-5$ to $t$.

In addition to gaining access through campaign support, firms can also obtain access to legislators by providing them with policy research. An important input into government policy decisions is the research that legislators receive on the economic viability of proposed legislation from firms' in-house policy analysts (Wright 1996). Typically, in-house policy analysts are part of the firms' government relations teams (Bremmer 2005). Thus, our next proxy for access to political information is the existence of a government relations division at the firm. Data on government relations staff come from Columbia Books \& Information Services' (CBIS) comprehensive historical dataset of firms' government relations offices. ${ }^{6}$ Our proxy for access to political information through a government relations office, GOVAFFAIRS, equals one if firm $i$ employed any government relations staff in year $t$, zero otherwise.

\footnotetext{
${ }^{6}$ CBIS was able to provide an electronic dataset beginning in 2011. For the earlier years in our sample, we hand collect data on firms' government relations data from Washington Representatives, a directory published semiannually by Columbia Books \& Information Services. We augment the electronic dataset provided by CBIS with our hand collected data.
} 


\subsection{Propensity to Guide: Sample and Descriptive Statistics}

To form our sample, we first merge the Compustat data with return data from CRSP, management guidance and analyst following data from $\mathrm{I} / \mathrm{B} / \mathrm{E} / \mathrm{S}$, political contribution data from the FEC files, and government relations staff data from CBIS to build a comprehensive database of firm contributions, government relations staff, annual firm accounting characteristics and performance, and guidance. ${ }^{7}$ We obtain data on the location of the firm's headquarters from two sources. We scrape the headers of firm's 10-K filings on EDGAR and fill any missing data with the locations reported on Compustat. Our initial sample contains 406,531 firm-quarter observations (representing 15,906 unique firms) for years 2001 through 2014. Our estimation sample requires non-missing data for all of the control variables, reducing our sample to 249,030 observations (9,846 unique firms). We also drop 416 observations that are singletons due to the use of firm fixed effects in our later analyses. Our final sample contains 248,614 firm-quarter observations from 9,430 unique firms.

Table 1 provides descriptive statistics for the sample. As shown in Panel A, just over $30 \%$ of our firm-quarter observations contain quarterly guidance and around $16 \%$ of our observations correspond to quarters when the firm is politically active. For these politically active firms, Panel B of Table 1 shows the incidence of guidance increases to 51.4\%, while the incidence of guidance for inactive firms is $26.4 \%$. This difference in the propensity to issue guidance between active and inactive firms is significant at the $1 \%$ level $(t=102.06)$. Further, we find that active firms use a greater number of policy-related words in their guidance $(t=$

\footnotetext{
${ }^{7}$ We obtain data on political contributions made by firm-sponsored political action committees from the FEC detailed committee and candidate summary contribution files. The FEC does not use company identifiers (i.e., CUSIP, PERMNO, etc.). Therefore, we match on historical company name using a computer-based algorithm. All matches generated from this fuzzy matching procedure are then manually screened to eliminate false positive matches. If we do not observe contributions for firm $i$ in any of the detailed committee and candidate summary contribution files, we code the number of candidates they support and their level of PAC contributions as zero.
} 
$116.51, p<0.01)$. These findings provide preliminary evidence that politically active firms have privileged access to policy-related information and disclose the effects of this information for the firm through increased voluntary disclosure. Panel B of Table 1 also compares additional firm characteristics for active and inactive observations. We observe that active firms are larger, tend to outperform their inactive counterparts (i.e., active firms report fewer loss quarters and amass greater annual returns), have lower return volatility, have higher leverage, attract more institutional investors, and are followed by an average of seven additional analysts. Further, connected firms are more likely to have the government as a major customer and their headquarters are located closer to Washington D.C. In the next subsection, we control for these observable differences across active and inactive firms. Further, in Section 5, we perform several additional tests to rule out the possibility that our findings for CONNECTED are due to correlated omitted variables.

\section{Empirical Tests: Propensity to Guide}

\subsection{Propensity to Guide Conditional on Political Access}

To test whether politically active firms are more likely to issue management guidance, we estimate the following linear probability model using OLS:

$$
\text { GUIDE }_{i t}=\alpha+\beta_{1} \text { CONNECTED }_{i t}+\gamma \text { CONTROLS }_{i t}+\varepsilon_{i t}
$$

where the propensity to issue guidance, GUIDE, is an indicator variable set to one in firmquarters where firm $i$ reports management guidance pertaining to net income (NET), earnings per share (EPS), fully reported earnings per share (EPS), EBITDA per share (EBT), and/or funds from operations (FFO); zero otherwise. We predict that the estimated coefficient on CONNECTED will be positively associated with GUIDE (i.e., $\beta_{1}>0$ ). 
We include additional controls $\left(C O N T R O L S_{i t}\right)$ that may influence firms' disclosure incentives. We draw these variables from prior research (e.g., Li and Zhang 2015; Huang, Jennings, and Yu 2017). First, we include stock returns (RETURN), return on assets (ROA), an indicator for loss firms (LOSS), and stock return volatility (RETVOL) to control for stock and financial performance. Second, we include the logarithm of market capitalization (SIZE), bookto-market ratio $(B T M)$, leverage ratio $(L E V)$, institutional ownership (INSTOWN), analyst following (FOLLOWING), and litigation risk (LITIGATION RISK) to control for the demand for information. (See Appendix A for additional detail on variable definitions.) We include yearquarter fixed effects to control for aggregate time-series trends. To mitigate concerns that timeinvariant industry characteristics affect our inferences, we estimate a version of equation (2) that further includes industry indicators based on the Fama-French 49 classification. Finally, standard errors are clustered at the firm level.

Table 2 provides the estimation results for equation (2). Regardless of whether industry fixed effects are included, we find that politically active firms are significantly more likely to issue management guidance relative to inactive firms, after controlling for typical firm characteristics that are associated with the decision to issue management guidance. Based on the results in column (1), the estimated coefficient on CONNECTED suggests that on average, politically active firms are five percentage points more likely to issue guidance relative to inactive firms $(p<0.01)$. This effect represents a 17\% increase in the likelihood of issuing guidance for politically active firms. ${ }^{8}$ In columns (3) and (4), we find similar evidence when we re-estimate equation (2) using the continuous measure CONNECTED $D_{\text {Candidate }}(p<0.01)$, suggesting that the propensity to guide is also increasing with the number of candidates

\footnotetext{
${ }^{8}$ If we set all control variables at their means, the probability for issuing guidance for connected (unconnected) firms is $32.3 \%(27.7 \%)$. Thus, connected firms have a $4.6 \%$ percent higher likelihood of issuing guidance (i.e., $32.3 \%-27.7 \%$ ), which translates into a $17 \%$ increase in the likelihood of issuing guidance (i.e., $4.6 \% / 27.7 \%$ ).
} 
supported. Finally, in columns (5) and (6), we re-estimate equation (2) using our indicator for whether or not the firm maintains a government relations office. In column (5), we find that firms with government relations offices are $7 \%$ more likely to issue guidance relative to firms without a government relations office $(p<0.01)$. The magnitude of is effect diminishes slightly to $5 \%$ when we include industry fixed effects in column $(6)(p<0.01)$. Overall, these results are consistent with our prediction that politically active firms are significantly more likely to issue management guidance relative to politically inactive firms.

\subsection{Cross-Sectional Variation in the Propensity to Guide Conditional on Political Access}

In this subsection, we examine whether politically active firms are even more likely to issue guidance when the firm's earnings have heightened exposure to policy decisions. We classify firms that report the federal government as a major customer during the fiscal year as firms that have a heightened exposure to policy decisions. We identify whether the federal government represents a major government customer from the Compustat Segments Customer data (Compustat item CTYPE). Specifically, we create an indicator variable, GOVCUST, that is equal to one if firm $i$ either reports the federal government as a major customer (i.e., CTYPE $=$ "GOVDOM") during the fiscal year or reports "COMPANY" in the CTYPE field and a branch of the federal government under the customer name field (Compustat item CNMS). Using this method, we identify 26,589 firm-quarters in our sample where the federal government is disclosed as a major customer. We re-estimate equation (2) including a main effect and an interaction effect for GOVCUST. We expect the coefficient on the interaction term of CONNECTED $\times$ GOVCUST to be positive.

Table 3 provides the results of this analysis. In columns (1) and (2), we find that the estimated coefficients on CONNECTED are positive and significant $(p<0.10)$, regardless of 
whether we exclude or include industry fixed effects. Further, the estimated coefficient on CONNECTED $\times G O V C U S T$ is positive and significant $(p<0.01)$, suggesting that politically active firms with heightened earnings exposure to government policies through government contracts are even more likely to issue guidance. In columns (3) through (6) we consider the number of connections that firms maintain (i.e., $C O N N E C T E D_{\text {Candidates }}$ ) or whether or not firms maintain a government relations office (i.e., GOVAFFAIRS). We continue to find that politically active firms reporting the federal government as a major customer are even more likely to issue guidance relative to inactive firms $(p<0.01)$. These findings suggest that politically active firms are even more likely to issue guidance when the federal government is a major customer. Taken together, the results in Tables 2 and 3 are consistent with the conclusion that the higher likelihood of issuing guidance is in part due to greater access to political information.

\subsection{Propensity to Guide: Policy Words}

If access to political information motivates firms to increase their voluntary disclosures, then we should observe that politically active firms mention more policy-related terms in their guidance. To investigate whether political access is related to the use of policy-related discussion in guidance disclosures, we use 8-Ks filed around guidance events to create two quarterly measures of policy word use. Both measures begin with all available 8-Ks on the SEC EDGAR website that were filed within five days (i.e., $t-2, t+2)$ around the earnings guidance date $(t)$ reported in $\mathrm{I} / \mathrm{B} / \mathrm{E} / \mathrm{S}$. We then count policy words mentioned in each guidance-related $8-\mathrm{K}$ disclosure and sum them at the firm-quarter level across all guidance-related 8-Ks. ${ }^{9}$ Our continuous measure of policy word use, POLICY WORDS, equals the number of policy words

\footnotetext{
${ }^{9}$ Rather than focus exclusively on the voluntary portion of firms' 8 -Ks (i.e., Item 2.02, 7.01, and 8.01) we gather all 8 -Ks around the guidance event and sum all policy-related words included in the entire 8-K. Treating all policy words used within 48 hours of a guidance event as voluntary is ideal in our setting because policy word used within any item is arguably voluntary, as guidance may trigger or be triggered by events that lead to filing other 8 -K items.
} 
used per 100 words in firm $i$ 's guidance-related 8 -K disclosure. ${ }^{10}$ Our dichotomous measure, HIGH POLICY WORDS, indicates firm-quarters where the firm's policy word use (i.e., unscaled POLICY WORDS) exceeds the $75^{\text {th }}$ percentile of sample observations. ${ }^{11}$ We then test our prediction by estimating the following model:

$$
\text { POLICY WORDS }_{i t}=\alpha+\beta_{1} \text { CONNECTED }_{i t}+\gamma \text { CONTROLS }_{i t}+\varepsilon_{i t}
$$

where the frequency of policy words is measured using POLICY WORDS, or HIGH POLICY WORDS. We predict that the estimated coefficient on CONNECTED will be positively associated with POLICY WORDS and HIGH POLICY WORDS (i.e., $\beta_{1}>0$ ). Additional controls $\left(C O N T R O L S_{i t}\right)$ are defined above. As before, we include industry, as well year-quarter fixed effects. We again cluster standard errors at the firm level.

Table 4 reports results from estimating equation (3) using OLS. In columns (1) through (3), we report the results using the HIGH POLICY WORDS indicator. We find that conditional on issuing guidance, politically active firms are also more likely to report policy terms with relatively high frequency in their guidance-related 8-K disclosures as compared to politically inactive firms. This holds regardless of which measure we use to capture firms' access to political information. Moreover, as shown in columns (4) through (6), our results are insensitive to estimating equation (3) using POLICY WORDS as the dependent variable.

Overall, the evidence presented in this section indicates that politically active firms are more likely to issue guidance, on average, than politically inactive firms, and this effect is more pronounced when firms have heightened earnings-exposure to federal policies (i.e., they report

\footnotetext{
${ }^{10}$ Baker et al. (2016) use several dictionaries related to various categories of economic policy uncertainty to develop an index of economic policy uncertainty (EPU). Their primary index is constructed daily based on the number of news articles that contain the terms "economic" or "economy", "uncertain" or "uncertainty", and one or more of "Congress," "deficit," "Federal Reserve," "legislation," "regulation," or "White House.” In our study, we include these terms as well as dictionary terms used in their categorical indices. See Appendix B for a list of terms that we use to identify POLICY WORDS.

${ }^{11}$ This measure is calculated using unscaled policy words to minimize the confounding impact that scaling by total words can induce when the total length of the filing changes due to reasons unrelated to policy words.
} 
the federal government as a major customer). Moreover, politically active firms are also more likely to include policy terms in their guidance-related $8-\mathrm{K}$ disclosures at a significantly higher rate as compared to politically inactive firms. Taken together, these results are consistent with firms' political activism providing disproportionate access to policy news. However, an alternative explanation for these findings is that investors in politically active firms demand more information because they face uncertainty over how political outcomes will impact the firm, even if the firm does not have inside political information. Additionally, our measures of political information flow could be correlated with an unobservable firm characteristic that increases propensity to guide. In the next section, we provide several additional tests to address these alternative explanations.

\section{Self-Selection and Timing Analyses}

In Section 4, we control for determinants of disclosure policy by including numerous firm characteristics in the regression model. However, it is possible that our measures for firms'

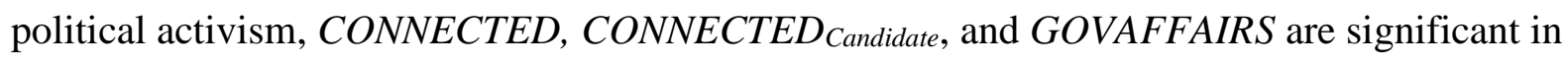
our analysis because they are correlated with another determinant that is excluded from or not fully controlled for in our regression models (such as general resources or political savviness). If this is true, the inference that firms gain access to political information through their political activism would not be valid.

To address this possibility, we perform two additional types of analyses. First, we perform additional econometric analyses to address the potential self-selection problem. These approaches include the use of entropy balancing, instrumental variables, firm fixed effects, and analysis of selection on unobservables to address the influence of both observable and 
unobservable characteristics correlated with CONNECTED and GUIDE on our inferences. Second, we study the timing of guidance in anticipation of industry-relevant legislation to better identify information flow. These analyses examine the extent to which politically active firms issue management guidance before legislative decisions are publicly revealed. Collectively, these additional tests provide further support for our conclusion that observed differences in management guidance by politically active firms stems in part from differential access to political information. The following subsections summarize the research design and results of these additional tests.

\subsection{Entropy Balancing}

As we observed in Table 1, Panel B, politically active firms differ from inactive firms along several dimensions. One concern with the validity of our findings is that observable differences across politically active and inactive firms explain differences in the propensity to issue guidance. To this end, in the prior sections we controlled for relevant observable characteristics in the regression model and included industry fixed effects throughout our analysis, accounting for the linear effect of the observable differences. In this section, following Hainmueller (2012), we employ entropy balancing to account for a possible non-linear effect stemming from these factors. Specifically, we balance the data across politically active and inactive firms relying on observable firm characteristics and repeat our analysis using this newly balanced data structure. Using methodology developed in Hainmueller (2012), we balance the data with respect to the first moment of observable firm characteristics for CONNECTED and GOVAFFAIRS. ${ }^{12}$ This procedure ensures that the observable features of firms with and without policy access have similar means. We are able to achieve covariate balance using entropy balancing (untabulated). We then re-estimate equation (2) using the entropy-balanced data

\footnotetext{
${ }^{12}$ We do not perform entropy balancing for CONNECTED $D_{\text {Candidate }}$ as it is a continuous variable.
} 
structure; the results are provided in Table 5. The table shows that results are robust to the use of entropy balancing: the coefficient on our measure of politically active remains significantly positive for both proxies examined $(p<0.01)$.

\subsection{Instrumental Variable Analysis}

Since empirical models are often incomplete/imperfect, in this subsection we examine the possibility that an unobservable correlated omitted variable may be driving the results. First, we use instrumental variables techniques to address self-selection based on unobservable characteristics. We instrument for a firm's political activism using a measure designed to capture how easy it would be for a firm representative to travel to Washington D.C.; proximity to Washington D.C. provides firms with greater access to government officials (Useem 1984). We believe this is a reasonable instrument because it is not clear why being closer to Washington D.C. would otherwise be correlated with firms' management guidance decisions. Table 6 report results from estimating equation (2) using a 2SLS instrumental variable approach where we instrument for firms' political connections using the distance (in thousands of miles) to Washington D.C. from the firm's headquarters (DISTANCE2DC), while controlling for firm characteristics and industry and year fixed effects. Columns (1), (3), and (5) of Table 6 report the results from the first-stage estimation. In all cases, we find that DISTANCE2DC is negatively and significantly related to firms' political activism $(p<0.01)$. This finding is consistent with the

notion that a shorter distance to Washington D.C. is a strong predictor of political connections. In the second stage estimation, reported in columns (2), (4), and (6), we find that our proxies for political activism remain positive and significant. 


\subsection{Firm Fixed Effects and Firms' Sensitivity to Policy Uncertainty}

To provide further evidence that our findings can be attributed to firms' differential access to political information, and not simply to an increase in voluntary disclosure in response to policy uncertainty, we perform two additional analyses in this subsection. First, to ensure that time-invariant firm uncertainty (or any other time-invariant firm characteristic) does not drive the increased likelihood to guide that we document, we include firm fixed effects in our regression models in addition to firm characteristics. The summary of these estimations is provided in Panel A of Table 7. The estimated coefficients on two of the three measures of political activism remain positive and significant. ${ }^{13}$ Taken together, the robustness of our results to the use of instrumental variable analysis and the inclusion of firm fixed effects suggest that an unobservable correlated omitted variable does not drive our findings.

The possibility still remains, however, that a time varying correlated omitted variable could also impact our results. For example, it is possible that a firm's political activism is simply correlated with their time-varying sensitivity to government policy exposure, and our political activism measures are simply capturing that sensitivity. To mitigate these concerns, we include an additional variable (EPU BETA) to control for any additional time-varying firm exposure to policy uncertainty. As reported in Table 7 Panel B, we continue to find similar results. Our inferences also hold if we include firm fixed effects in addition to EPU BETA (not tabulated). Taken together, these additional analyses suggest that our findings can be attributed to differential access to political information rather than other firm characteristics.

\footnotetext{
${ }^{13}$ As an alternative approach to gauge the potential impact of unobservables on our results, we estimate a series of models with and without controls and use the stability of the coefficient on our proxies for political access and $\mathrm{R}^{2}$ to quantify the minimum level of selection on unobservables required to create our results. To do this, we follow the approach introduced in Altonji, Elder, and Taber (2005) as operationalized by Oster (2017). Based on the model reported in column (1) of Table 7 panel A, the methods outlined in Oster (2017) suggest that selection on unobservables would need to account for $212 \%$ of the variation accounted for by the included controls (results not tabulated).
} 


\subsection{Timing of Guidance around Political Events}

One concern with our prior results is that they do not provide direct evidence on the differential flow of political information. To provide additional support for our inferences, we study differences in the timing of guidance around legislative events. We conjecture that, if politically active firms have access to political information, then active firms should communicate earlier than their inactive peers around political events that are equally important to active and inactive firms.

To identify legislation that impacts firms in our sample, we rely on a sample of legislative bills where either (1) the focal firm (or a peer) lobbied for the bill (signaling the bill is economically important to the focal firm and/or peer firm), and (2) the bill was ultimately signed into law. ${ }^{14,15}$ Lobbying disclosures include details on the total amount of lobbying dollars spent by firms across all issues (e.g., taxation, budget and appropriation, healthcare, etc.). ${ }^{16}$ In addition to providing details on the issues of interest to the firm, the lobbying disclosures also include details on specific bills. ${ }^{17}$ We obtain the date each bill is introduced and the date of each bill's final vote before it is signed into law from ProPublica's Congress API. ${ }^{18}$ While each bill is voted on many times throughout its life, we focus on the final roll call vote as this is the date on which

\footnotetext{
${ }^{14}$ This approach has similar intuition to that of Cohen et al. (2013). They develop a methodology designed to measure the impact of legislation on affected firms (and industries) by mapping terms used for industry classifications to the language in legislative proposals under the assumption that most legislative changes tend to apply to entire industries, rather than to specific firms.

${ }^{15}$ Lobbying reports are filed with the Secretary of the Senate's Office of Public Records and are available by calendar year beginning in 1998. The Center for Responsive Politics (CRP) maintains the lobbying data, which we manually match to Compustat by company name. The lobbying reports disclose specific bills that firms lobby for.

${ }^{16}$ The full list of lobbying issue codes can be found on the House.gov website: https://lobbyingdisclosure.house.gov/help/default.htm?turl=WordDocuments\%2Flobbyingissuecodes.htm. There are a total of 79 issue codes.

${ }^{17}$ For example, from reviewing Lockheed Martin's 2014 lobbying disclosures, we learn that the firm spent over \$14 million on lobbying and lobbied over policies pertaining to defense, the federal budget and appropriations, aviation, and taxes. Some of the specific bills that Lockheed Martin targeted include: the Howard P. "Buck" McKeon National Defense Authorization Act for Fiscal Year 2015 (H.R.4435), Carl Levin National Defense Authorization Act for Fiscal Year 2015 (S.2410), and the Department of Defense Appropriations Act, 2015 (H.R.4870). This detail was pulled from OpenSecrets.org: https://www.opensecrets.org/lobby/clientsum.php?id=D000000104\&year=2014. ${ }^{18}$ https://projects.propublica.org/api-docs/congress-api/
} 
virtually all uncertainty around the bill's fate is removed. These procedures yield 415 bills that firms lobbied on and were ultimately passed into law. Using these events, we can identify the period before and including the passage of legislation likely to impact the firm, providing a setting to test our information flow hypothesis. This design helps mitigate differences in government policy sensitivity across firms by including in our analysis only those firms that either directly lobbied for the legislation or are product-market peers of the lobbying firm(s).

We conjecture that, if firms obtain information about legislative outcomes through their political access, then firms with access should communicate more than their inactive peers in the days before enactment (i.e., prior to public knowledge of the final details and outcome of the final vote). To focus on voluntary guidance that is likely driven by the access to legislative outcomes, we eliminate guidance observations issued around the firm's earnings announcement. We examine all non-earnings announcement guidance issued by focal firms or their peers in the 30 days before and 30 days after the final roll call vote for bills that the focal firm lobbies for. We then calculate the number of days between the guidance and the final roll call vote. We identify peers using Hoberg and Phillips' (2010) product-description-based classifications rather than industrial classifications. We do this because appropriations bills dominate other forms of legislation in our sample; therefore, as appropriations concern eligible bidders for procurement contracts most directly, we feel that product description-based classifications are the most relevant peer group definition. ${ }^{19}$

To test our conjecture that firms with access to private political information are more likely to issue guidance before the final roll call vote, we analyze whether the distribution of the timing of guidance by firms with political access differs from the distribution of the timing of

\footnotetext{
${ }^{19} \mathrm{We}$ read the titles and topics of a sample of 250 of the 415 bills in this analysis. Of the 250,121 bills are appropriations bills, 26 concern regulation, and 19 concern taxation. The remainder are a mix related to immigration (H1b visas), subsidies, and trade bills.
} 
guidance by firms without political access around the final vote. To provide statistical tests of our conjecture, we use Epanechnikov kernel density estimates. ${ }^{20}$ Kernel density estimation uses observed data to estimate the distribution function that generated the data. Though inspection of density plots can be quite convincing, we provide several distributional tests to confirm our inferences from the density plots. First, we use the Kolmogorov-Smirnov (K-S) test, which tests of the hypothesis that two samples come from the same distribution. ${ }^{21}$ In addition to testing for equality of distributions, the K-S test allows us to test directional hypotheses around the date of the final roll call. We supplement the K-S test with the Epps-Singleton (E-S) test, which is more robust for testing the equality of distributions of discrete data. We conduct these tests using both CONNECTED and GOVAFFAIRS to measure political access.

Figure 1 plots the Epanechnikov kernel density estimates of non-earnings announcement guidance issued in the 60 days around the final roll call vote (i.e., 30 days before and 30 days after) for connected and unconnected firms with $95 \%$ confidence intervals. Consistent with our conjecture, we observe that guidance issued by CONNECTED firms is concentrated in the prevote period, and this difference is significant at the $5 \%$ level for the two weeks leading up to the final vote.

The first row of Panel A of Table 8 reports a K-S test of the hypothesis that inactive firms $(C O N N E C T E D=0)$ are more likely to guide in the 30 days before and after the final roll call vote than their politically active peers $(C O N N E C T E D=1)$. Consistent with our expectations, we reject this hypothesis before the vote and fail to reject it following the vote. The second row of Table 8 reports a K-S test of the hypothesis that unconnected firms $(C O N N E C T E D=0)$ are less

\footnotetext{
${ }^{20}$ A natural question is why, when faced with discrete data (naturally binned by days), we chose to use kernel density estimation. Weekends, during which there is little voting and guidance activity, create a large amount of noise in the plot making the differences in the distributions impossible to visualize without non-day binning.

${ }^{21}$ Although the K-S test was developed for continuous data, Conover (1972) shows that this test is conservative for discrete data.
} 
likely to guide in the 30 days before and after the final roll call vote than their connected peers $(C O N N E C T E D=1)$. Consistent with our expectations, we fail to reject this hypothesis before the vote and reject it following the vote. The third row of Panel A and Panel B report K-S and E-S tests, respectively, of the hypothesis that the distributions of guidance by connected and nonconnected firms are equal in the pre and post vote period. We are able to reject this hypothesis under both tests in the pre period $(p<0.01)$ and post period $(p<0.09)$. In untabulated analyses, we find these results hold when comparing the distribution of guidance across firms with and without government relations offices.

A disadvantage of this distributional analysis is that it is not able to control for observable and unobservable differences between the two groups. We perform two tests to determine if our results are induced by differences that are not controlled for. First, as a falsification test, we examine guidance that is bundled with earnings announcements. Our tests above rely on the notion that firms choose to issue guidance when they gain access to political information, and thus assumes that the firm can choose the date on which it issues guidance. If firm characteristics or other unobservable factors induce the findings in Panel A of Table 8 for the timing of nonbundled guidance, we should continue to find significant differences in the relative timing of bundled guidance. In untabulated analysis, we find that firms with and without political access are equally likely to issue bundled guidance in the days around the final vote, and that neither group exhibits the clear pre-vote spike and post-vote slump in bundled guidance exhibited in Figure 1.

As an alternative way to address the potential effect of observable factors, we model the timing of guidance around the final roll call vote as a function of the firm-level observables used in Table 2. Specifically, we estimate the following model: 


$$
\text { TIMING }_{i t}=\alpha+\beta_{1} \text { CONNECTED }_{i t}+\gamma \text { CONTROLS }_{i t}+\varepsilon_{i t}
$$

where negative (positive) values of TIMING measure the number of days that guidance is issued before (after) the legislation. Thus, TIMING ranges from -30 to +30 . In addition to the set of controls included previously, we include fiscal quarter and firm fixed effects. Moreover, to ensure that we are not attributing our findings to a mechanical correlation between the timing of bills and firms' fiscal calendars, we include calendar month indicators. Consistent with our expectation that politically active firms will issue guidance sooner relative to unconnected firms, column (1) of Table 8, Panel C shows that the estimated coefficient on CONNECTED is significantly negative. The negative coefficient is consistent with the distributional analysis presented in Panel A.

Next, we analyze the distribution of guidance leading up to and following the final roll call vote conditional on the length of time between introduction of the bill and enactment. We expect differential access to political information is increasing with the length of time between introduction and the final roll call vote. Thus, we expect more dramatic differences between active and inactive firms in pre-enactment window with the bill moves less rapidly through the legislative process (i.e., political information is more valuable when bills are more controversial). We classify a vote as slow when the time between introduction and enactment exceeds the first quartile of bill speeds of eight weeks (56 days). The first quartile of bill speeds corresponds to the notional expected speed of a bill that experiences no delays. ${ }^{22}$

\footnotetext{
${ }^{22}$ In each chamber (House and Senate) a bill must (1) be introduced, numbered, and assigned to a committee; (2) read, debated, and voted on in committee; and (3) returned to the chamber for debate and vote. Once both houses have voted, any differences in the two bills are voted upon as amendments in reconciliation. Based on the congressional calendar and observations of the function of both houses, we expect that the minimum time required for each step to be no less than one week (see https://thinkprogress.org/the-three-day-workweek-d4944a813746/, https://www.newyorker.com/magazine/2010/08/09/the-empty-chamber, and https://www.congress.gov/days-insession).
} 
Figure 2 plots the densities of guidance for firms with and without political access around the final vote for bills that move through both houses of Congress in less than eight weeks. These densities rarely diverge and critically overlap for the two weeks leading up to the vote. This is consistent with the notion that the firms do not have material, nonpublic information to disclose to their investors. In contrast, Figure 3 plots densities for the same groups over the same period, but for bills that take more than eight weeks to pass. In this subsample, we find that the effect evident in Figure 1 is even more pronounced. The difference in findings between Figures 2 and 3 could be a result of two potential mechanisms: first, fast bills may move too quickly for firms to gather and release information; second, fast bills may be unimportant, uncontroversial, or not associated with high levels of uncertainty. Thus, while information may be available to the firm, the firm may see no value in releasing the information. To determine if this result holds in the multivariate setting, we also conduct a cross-sectional test where we define the variable FAST to be equal to one when the bill is passed in fewer than eight weeks and zero otherwise. In column (2) of Table 8, Panel B, we present the results from estimating equation (3) including FAST and its interaction with CONNECTED. Consistent with Figures 2 and 3, we find that the results in column (1) are concentrated in the bills that pass in more than eight weeks.

Finally, we examine whether changes in the language accompanying guidance issued around these legislative events is consistent with differences in access to private political information. We argue that Figures 1 and 3, and Table Panels A, B, and C are suggestive of firms using their access to amass private political information and then releasing this information to investors in the two weeks prior to the legislative action. If this spike in disclosure is driven, as we argue, by the arrival of new information, then we expect a greater change in the government 
policy related discussion contained in this guidance for firms with political access compared to their peers firms without access.

To test our prediction, we compare the government policy words used in the text of guidance issued in the two weeks prior to the date of the final vote (i.e., treatment) to guidance issued in the 90 days prior to the date the bill is introduced that is also bundled with earnings announcements (i.e., benchmark). By using bundled earnings guidance as our benchmark, we assume that the earnings announcement, not access to private political information, drives the decision to issue the benchmark guidance. In essence, we assume that the language used in the benchmark guidance reflects general firm characteristics (such as general exposure to policy uncertainty), and thus any difference in language used in the treatment guidance reflects private political information.

To evaluate how similar the use of policy words is between legislative guidance and earnings announcement guidance, we calculate the cosine difference between the two texts. We use the token frequency- inverse document frequency (TF-IDF) weighted cosine difference as this measure puts less weight on common words. The cosine difference increases as the two texts become more dissimilar. In Panel D of Table 8, we regress the TF-IDF weighted cosine distance on CONNECTED and our control variables. As we did in the timing analysis above, we again limit our sample to firms that compete with firms that lobby for the bills around which we calculate our measures and include industry fixed effects. Thus the coefficient on CONNECTED captures the extent to which the change in the information disclosed with guidance differs between firms with political access and their product market competitors.

We find that the estimated coefficient on CONNECTED is positive and significant, indicating that, relative to inactive firms, the guidance politically active firms issue in the two 
weeks prior to a legislative final vote is more dissimilar to that firm's bundled earnings guidance issued prior to the introduction of the bill. This analysis suggests that firms with political access change the information set accompanying their guidance more prior to legislative actions than their peers without access. While our measure of new information (TF-IDF weighted cosine distance) does not pinpoint precisely which policy-words are emphasized differently prior to the legislative final vote, the measure does demonstrate a change in the use of policy-related words for politically active firms. This evidence is consistent with politically active firms having access to different information than politically inactive firms and voluntarily disclosing that information to investors.

To further address concerns that this change in information set is due to a change in the demand for information rather than the supply of information, we conduct two additional untabulated analyses. First, we repeat the analysis including EPU BETA as a control for the firm's sensitivity to government policy uncertainty over time and thus variation in the demand for information. The findings in Table 8 Panel D continue to hold with this additional control. Second, we restrict the sample to only government contractors, who are most directly impacted by the legislation, in order to focus on firms whose exposure to legislative action is more comparable. We again find results similar to those reported in Table 8 Panel D for this subsample. Taken together, these additional analyses support our central conjecture that firms that generate private information through political access release it to their shareholders.

\section{Conclusions}

In this study, we examine whether and how political information is disclosed to market participants. We document that firms who are politically active are more likely to issue guidance, especially when the federal government is a major customer. Moreover, politically active firms 
include more policy-related terms in their guidance disclosures than politically inactive firms. These findings are robust to various econometric techniques to control for the endogenous decision to become politically active. As additional evidence that access to political information induces firms to issue guidance, we examine the timing and content of guidance relative to the passage of bills that potentially impact the firm. We find that politically active (inactive) firms are significantly more likely to issue non bundled guidance in the period immediately before (after) legislation is passed. Moreover, the similarity in policy-related language between guidance issued immediately before legislation is passed and bundled earnings guidance issued prior to the introduction of the bill is lower for politically active firms than politically inactive firms. Overall, our results are consistent with politically active firms obtaining privileged access to policy-related information and incorporating it into the guidance they provide investors, thereby facilitating the flow of political information to the market. 


\section{REFERENCES}

Anantharaman, D. and Y. Zhang. 2011. Cover me: Managers' responses to changes in analyst coverage in the post-regulation FD period. The Accounting Review 86(6): 1851-1885.

Baker, S., N. Bloom, and S. Davis. 2016. Measuring economic policy uncertainty. Quarterly Journal of Economics 131: 1593-1636.

Balakrishnan, K., M. Billings, B. Kelly, and A. Ljungqvist. 2014. Shaping liquidity: On the causal effects of voluntary disclosure. Journal of Finance 69(5): 2237-2278.

Bamber, L. and Y.S. Cheon. 1998. Discretionary management earnings forecast disclosures: Antecedents and outcomes associated with forecast venue and forecast specificity choices. Journal of Accounting Research 36(2): 167-190.

Beyer, A., D. Cohen, T. Lys, and B. Walther. 2010. The financial reporting environment: Review of the recent literature. Journal of Accounting and Economics 50(2-3): 296-343.

Billings, M.B., R. Jennings, and B. Lev. 2015. On guidance and volatility. Journal of Accounting and Economics 60(2-3): 161-180.

Bremmer, I. 2005. Managing risk in an unstable world. Harvard Business Review 83(6): 51-60.

Cao, S.S., G. Ma, J.W. Tucker, and C. Wan. 2018. Technological peer pressure and product disclosure. The Accounting Review 93(6): 95-126.

Choi, J., L. Gallo, R. Hann, and H. Kim. 2019. Does management guidance help resolve uncertainty around macroeconomic announcements? Working paper.

Christensen, D., M. Mikhail, B. Walther, and L. Wellman. 2017. From K Street to Wall Street: Political connections and stock recommendations. The Accounting Review 92: 87-112.

Cohen, L., K. Diether, and C. Malloy. 2013. Legislating stock prices. Journal of Financial Economics 110(3): 574-595.

Cooper, M.J., H. Gulen, and A.V. Ovtchinnikov. 2010. Corporate political contributions and stock returns. Journal of Finance 65: 687-724.

Ferracuti, E., R. Michaely, and L. Wellman. 2019. Timing is everything: Political activism and market share. Working paper.

Gao, M. and J. Huang. 2016. Capitalizing on Capitol Hill: Informed trading by hedge fund managers. Journal of Financial Economics 121(3): 521-545.

Guay, W., D. Samuels, and D. Taylor. 2016. Guiding through the fog: Financial statement complexity and voluntary disclosure. Journal of Accounting and Economics 62(2-3): 234269. 
Hainmueller, J., 2012. Entropy balancing for causal effects: A multivariate reweighting method to produce balanced samples in observational studies. Political Analysis 20(1): 25-46.

Hassan, T., S. Hollander, L. van Lent, and A. Tahoun. 2019. Firm-level political risk: Measurement and effects. Quarterly Journal of Economics, forthcoming.

Heltman, J., 2015. Why the public can't read the press. The Atlantic (November). Accessed at: http://www.theatlantic. com/politics/archive/2015/11/washingtontradepress/417366/. Accessed 31 December 2015

Hoberg, G. and G. Phillips. 2010. Product market synergies and competition in mergers and acquisitions: A text-based analysis. Review of Financial Studies 23(10): 3773-3811.

Hojnacki, M. and D.C. Kimball. 2001. PAC contributions and lobbying contacts in congressional committees. Political Research Quarterly 54(1): 161-180.

Humphries, C. 1991. Corporations, PACs and the strategic link between contributions and lobbying activities. Western Political Quarterly 353-372.

Hung, M., Y. Kim, and S. Li. 2018. Political connections and voluntary disclosure: Evidence from around the world. Journal of International Business Studies 49(3): 272-302.

Jagolinzer, A., D. Larcker, G. Ormazabal, and D. Taylor. 2018. Political connections and the informativeness of insider trades. Working paper.

Jerke, B. W. 2010. Cashing in on Capitol Hill: Insider trading and the use of political intelligence for profit. University of Pennsylvania Law Review 158(5): 1451-1521.

Kelly, B., L. Pástor, and P. Veronesi. 2016. The price of political uncertainty: Theory and evidence from the option market. Journal of Finance 71: 2417-2480.

Mullins, B. 2012a. Wall Street, Washington and Gingrich. The Wall Street Journal (January 13). Available at: http://www.wsj.com/video/wall-street-washington-and-gingrich/4E5CBB03318B-4D77-9D63-D0691BB32928.html.

Mullins, B. 2012b. New bill clouds legality of tips. The Wall Street Journal (February 16): C1.

Mullins, B. 2014. Lawmakers plan to introduce bill regulating "political intelligence.' The Wall Street Journal (September 17). Available at: http://www.wsj.com/articles/lawmakers-plan-tointroduce-bill-regulating-political-intelligence-1410987534

Nagar, V., J. Schoenfeld, and L. Wellman. 2019. The effect of economic policy uncertainty on investor information asymmetry and management disclosures. Journal of Accounting and Economics 67: 36-57. 
Nagy, D.M. and R.W. Painter. 2012. Selective disclosure by federal officials and the case for an FGD (Fairer Government Disclosure) regime. Wisconsin Law Review 1285-1366.

Ovtchinnikov, A., S.W. Reza; and Y. Wu. 2019. Political activism and firm innovation. Journal of Financial and Quantitative Analysis, forthcoming.

Pástor, L., and P. Veronesi. 2012. Uncertainty about government policy and stock prices. Journal of Finance 67: 1219-1264.

Pástor, L', and P. Veronesi. 2013. Political uncertainty and risk premia. Journal of Financial Economics 110: 520-545.

Schuler, D., K. Rehbein, and R. Cramer. 2002. Pursuing strategic advantage through political means: A multivariate approach. Academy of Management Journal 45(4): 659-672.

Useem, M. 1984. The Inner Circle: Large Corporations and the Rise of Business Political Activity in the U.S. and U.K. New York, NY: Oxford University Press.

Verrecchia, R.E. 1990. Information quality and discretionary disclosure. Journal of Accounting and Economics 12(4): 365-380.

Verrecchia, R.E. and J. Weber. 2006. Redacted disclosure. Journal of Accounting Research 44(4): 791-814.

Wellman, L. 2017. Mitigating political uncertainty. Review of Accounting Studies 22(1): 217250.

Wright, J.R. 1996. Interest groups and Congress: Lobbying, contributions, and influence. Allyn \& Bacon. 


\section{APPENDIX A Variable Definitions}

Variable Name

GUIDE

POLICY WORDS

HIGH POLICY WORDS

TIMING

CONNECTED

CONNECTED $D_{\text {Candidate }}$

GOVAFFAIRS

GOVCUST

SIZE

BTM

DLOSS

RETURN

$R O A$

RETVOL

LEV

INSTOWN $\underline{\text { Description }}$

An indicator variable set to one in firm-quarters where firm $i$ reports management guidance pertaining to net income, earnings per share, fully reported earnings per share, EBITDA, EBITDA per share, and/or funds from operations, zero otherwise.

The number of policy words per 100 words within 8-Ks that correspond to guidance. Policy words are defined based on Baker et al. (2016). Appendix B contains a complete list of the policy words.

An indicator variable set equal to one for firm-quarters in which the aggregate number of policy words in the firm's 8-Ks are above the $75^{\text {th }}$ percentile in sample period, zero otherwise.

The number of days that guidance is issued before (after) legislation. This variable ranges from -30 to +30 .

Indicates whether the firm reports any hard-money Political Action Committee contributions during fiscal year $t$.

The natural logarithm of 1 plus the number of political candidates (House, Senate, and Presidential) that the firm contributed money to over years $t-5$ to $t$.

An indicator variable set equal to one if the firm had a government affairs office during year $t$, zero otherwise.

An indicator variable set equal to one if the firm reported the U.S. federal government as one of its major customers during year $t$, zero otherwise.

The natural logarithm of the firm's beginning-of-quarter market capitalization.

The firm's beginning-of-quarter book-to-market ratio.

An indicator variable set equal to one if the firm reports a loss in the current quarter, zero otherwise.

The firm's cumulative daily returns over the 12 months prior to quarter $t$.

The firm's net income divided by total assets at the beginning of quarter $t$.

The standard deviation of the firm's daily stock returns over the 12 months prior to quarter $t$.

The firm's debt divided by total assets at the beginning of quarter $t$.

The percentage of the firm's shares held by institutional investors at the beginning of quarter $t$. 


\section{APPENDIX A, CONT. Variable Definitions}

Variable Name

FOLLOWING

LITIGATION RISK

DISTANCE2DC

FAST

EPU BETA
Description

The natural log of the number of analysts issuing a forecast for the current fiscal quarter as reported in $\mathrm{I} / \mathrm{B} / \mathrm{E} / \mathrm{S}$.

An indicator variables set equal to one if the firm operates within a litigious 4-digit SIC code, zero otherwise.

The distance (measured in thousands of miles) to Washington D.C. from the firm's headquarters, as reported in Compustat.

An indicator variable set equal to one if the bill passed in fewer than 56 days, zero otherwise.

The sensitivity of the firm's daily stock returns to the daily economic policy uncertainty (EPU) index over the prior fiscal quarter. 


\section{APPENDIX B \\ Policy Term List from Baker et al. (2016)}

Category
Entitlement Programs

Financial Regulation

Fiscal Policy and Government Spending

Health Care

Monetary Policy

National Security $\underline{\text { Term Sets }}$

entitlement program, entitlement spending, government entitlements, social security, Medicaid, Medicare, government welfare, welfare reform, unemployment insurance, unemployment benefits, food stamps, afdc, tanf, wic program, disability insurance, part d, oasdi, Supplemental Nutrition Assistance Program, Earned Income Tax Credit, EITC, head start program, public assistance, government subsidized housing

banking supervision, glass-steagall, tarp, bank supervision, thrift supervision, dodd-frank, financial reform, commodity futures trading commission, cftc, house financial services committee, basel, capital requirement, Volcker rule, bank stress test, securities and exchange commission, sec, deposit insurance, fdic, fslic, ots, occ, firrea, truth in lending

government spending, federal budget, budget battle, balanced budget, defense spending, military spending, entitlement spending, fiscal stimulus, budget deficit, federal debt, national debt, Gramm-Rudman, debt ceiling, fiscal footing, government deficits, balance the budget

health care, Medicaid, Medicare, health insurance, malpractice tort reform, malpractice reform, prescription drugs, drug policy, food and drug administration, FDA, medical malpractice, prescription drug act, medical insurance reform, medical liability, part d, affordable care act, Obamacare

federal reserve, the fed, money supply, open market operations, quantitative easing, monetary policy, fed funds rate, overnight lending rate, Bernanke, Volcker, Greenspan, central bank, interest rates, fed chairman, fed chair, lender of last resort, discount window, European Central Bank, ECB, Bank of England, Bank of Japan, BOJ, Bank of China, Bundesbank, Bank of France, Bank of Italy

national security, war, military conflict, terrorism, terror, 9/11, defense spending, military spending, police action, armed forces, base closure, military procurement, saber rattling, naval blockade, military embargo, no-fly zone, military invasion 


\section{APPENDIX B, CONT. \\ Policy Term List from Baker et al. (2016)}

Category

Regulation

Sovereign Debt, Currency

Crises

Taxes

Trade Policy $\underline{\text { Term Sets }}$

regulation, banking supervision, glass-steagall, tarp, bank supervision, thrift supervision, dodd-frank, financial reform, commodity futures trading commission, cftc, house financial services committee, basel, capital requirement, Volcker rule, bank stress test, securities and exchange commission, sec, deposit insurance, fdic, fslic, ots, occ, firrea, truth in lending, union rights, card check, collective bargaining law, national labor relations board, nlrb, minimum wage, living wage, right to work, closed shop, wages and hours, workers compensation, advance notice requirement, affirmative action, at-will employment, overtime requirements, trade adjustment assistance, davis-bacon, equal employment opportunity, eeo, osha, antitrust, competition policy, merger policy, monopoly, patent, copyright, federal trade commission, ftc, unfair business practice, cartel, competition law, price fixing, class action, healthcare lawsuit, tort reform, tort policy, punitive damages, medical malpractice, energy policy, energy tax, carbon tax, cap and trade, cap and tax, drilling restrictions, offshore drilling, pollution controls, environmental restrictions, clean air act, clean water act, environmental protection agency, epa, immigration policy

sovereign debt, currency crisis, currency crash, currency devaluation, currency revaluation, currency manipulation, euro crisis, Eurozone crisis, european financial crisis, european debt, asian financial crisis, asian crisis, Russian financial crisis, Russian crisis, exchange rate taxes, tax, taxation, taxed import tariffs, import duty, import barrier, government subsidies, government subsidy, wto, world trade organization, trade treaty, trade agreement, trade policy, trade act, doha round, uruguay round, gatt, dumping 
FIGURE 1

Plots of Epanechnikov Kernel Density Estimates (EKDE) Around Final Vote Date ${ }^{a}$

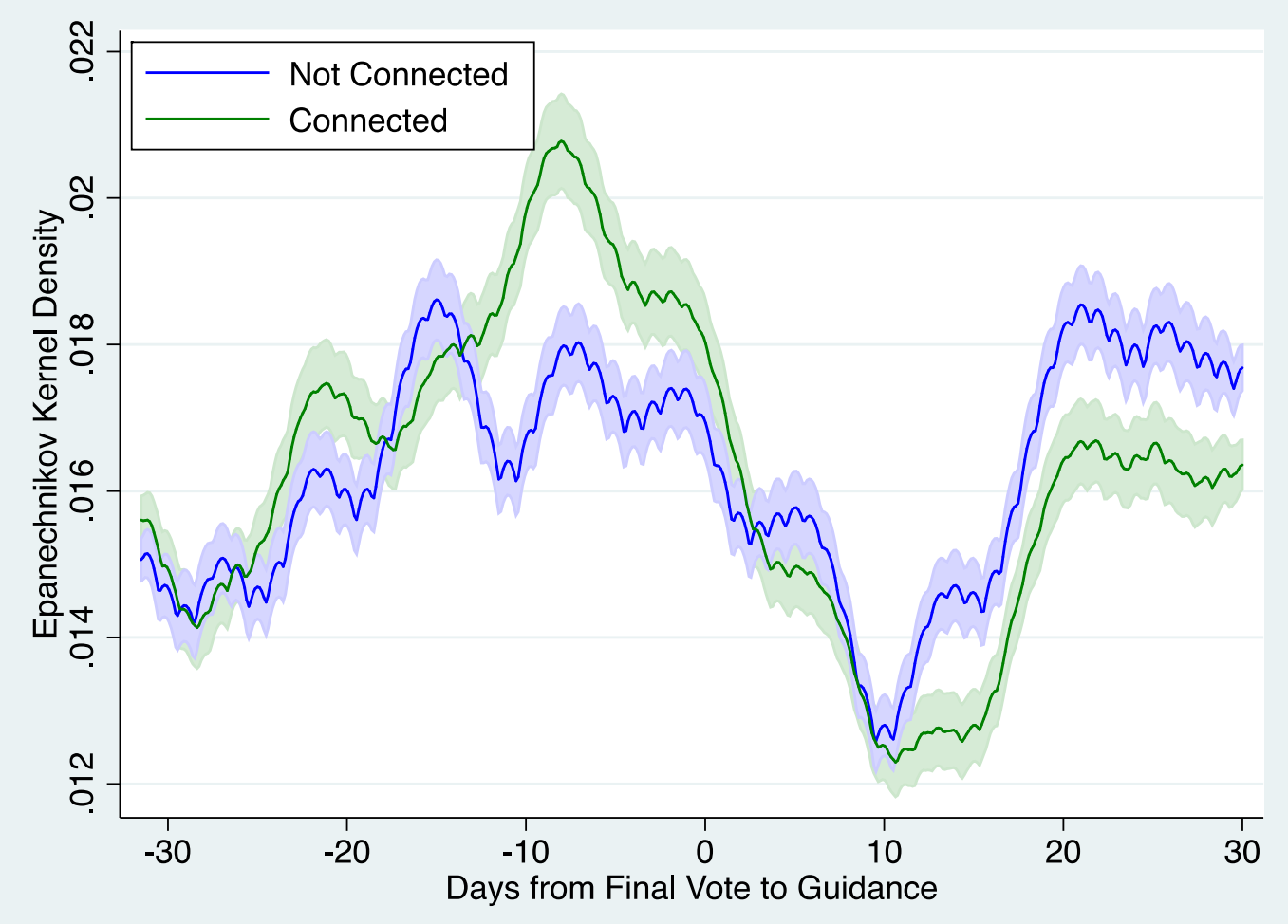

${ }^{a}$ This figure provides the EKDE estimates and $95 \%$ confidence intervals around the final vote date. The sample excludes earnings announcement guidance. 
FIGURE 2

Plots of Epanechnikov Kernel Density Estimates (EKDE) for "Fast" Bills Around Final Vote Date

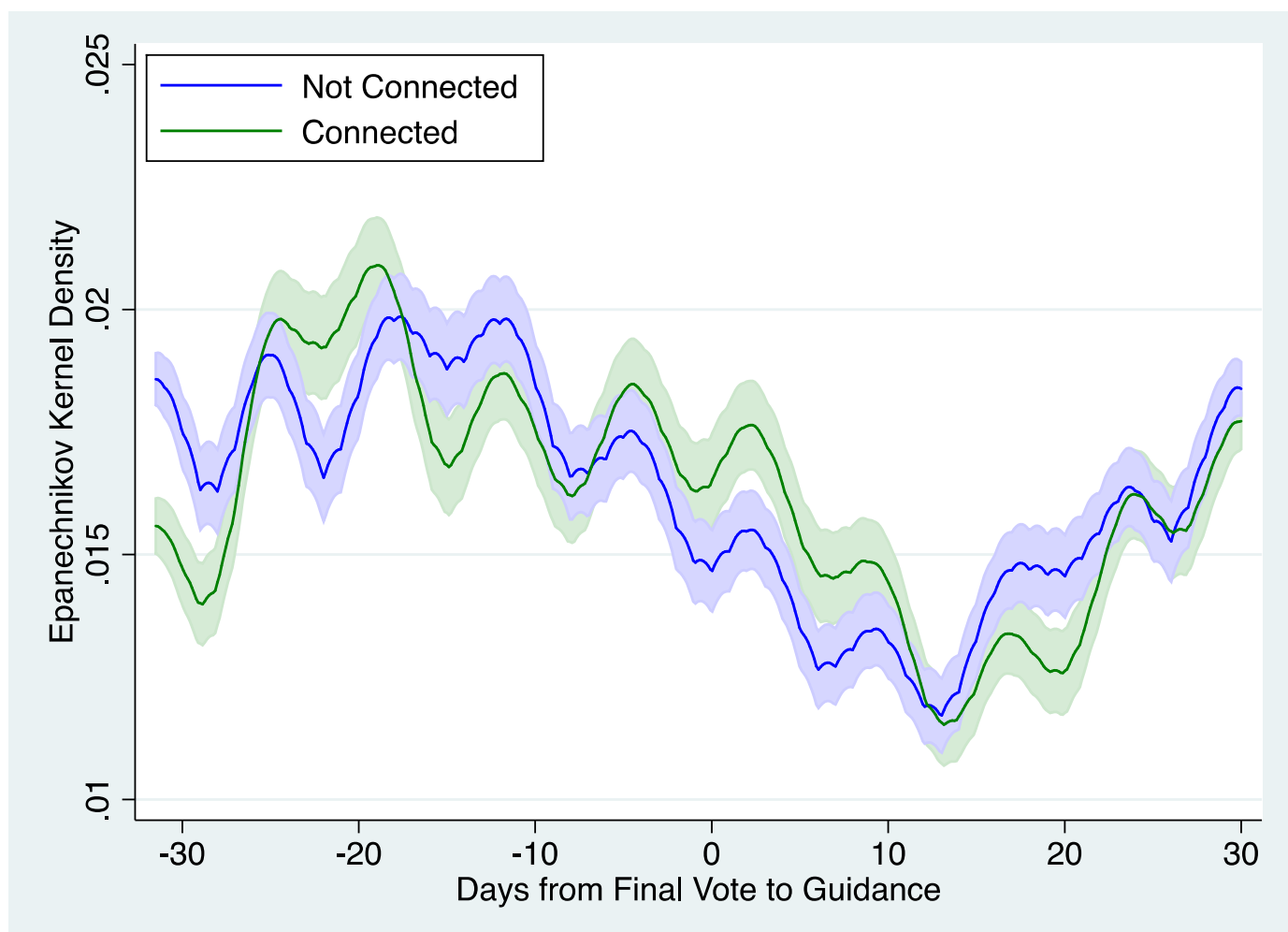

${ }^{a}$ This figure provides the EKDE estimates and 95\% confidence intervals around the final vote date for "fast" bills. A bill is defined as "fast" if it moves through both houses of Congress in less than eight weeks. The sample excludes earnings announcement guidance. 
FIGURE 3

Plots of Epanechnikov Kernel Density Estimates (EKDE) for "Slow" Bills Around Final Vote Date

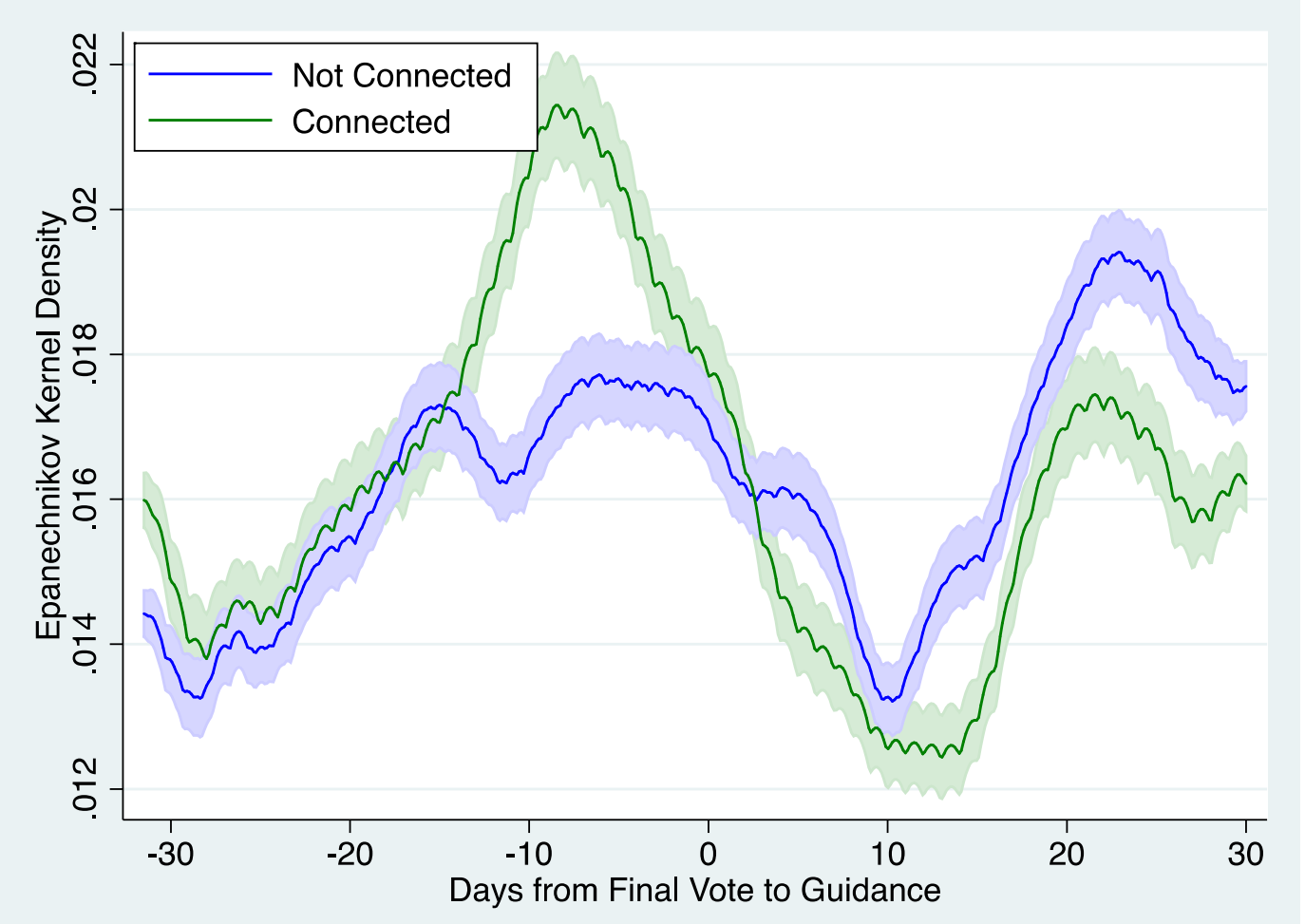

a This figure provides the EKDE estimates and 95\% confidence intervals around the final vote date for "slow" bills. A bill is defined as "fast" if it moves through both houses of Congress in more than eight weeks. The sample excludes earnings announcement guidance. 


\begin{tabular}{|c|c|c|c|c|c|}
\hline \multicolumn{6}{|c|}{$\begin{array}{c}\text { TABLE 1 } \\
\text { Summary Statistics }\end{array}$} \\
\hline \multicolumn{6}{|c|}{ Panel A: Descriptive Statistics for Full Sample $(\mathrm{N}=248,614)$} \\
\hline Variable $^{\mathrm{a}}$ & Mean & Std. Dev. & $\underline{\mathrm{P} 25}$ & $\underline{\text { Median }}$ & $\underline{\mathrm{P} 75}$ \\
\hline$\overline{G U I D E}$ & $\overline{0.305}$ & 0.460 & 0.000 & 0.000 & $\overline{1.000}$ \\
\hline POLICY WORDS & 0.216 & 0.355 & 0.000 & 0.000 & 0.455 \\
\hline CONNECTED & 0.162 & 0.369 & 0.000 & 0.000 & 0.000 \\
\hline CONNECTED $D_{\text {Candidate }}$ & 14.554 & 56.337 & 0.000 & 0.000 & 0.000 \\
\hline GOVAFFAIRS & 0.047 & 0.213 & 0.000 & 0.000 & 0.000 \\
\hline$S I Z E$ & 5.998 & 2.123 & 4.470 & 5.961 & 7.418 \\
\hline $\log (B T M)$ & -0.681 & 0.898 & -1.166 & -0.615 & -0.135 \\
\hline$L O S S$ & 0.321 & 0.467 & 0.000 & 0.000 & 1.000 \\
\hline RETURN & 0.142 & 0.684 & -0.226 & 0.054 & 0.344 \\
\hline RETVOL & 0.035 & 0.022 & 0.020 & 0.029 & 0.044 \\
\hline$L E V$ & 0.204 & 0.205 & 0.017 & 0.152 & 0.327 \\
\hline FOLLOWING & 5.325 & 6.362 & 0.000 & 3.000 & 8.000 \\
\hline LITIGATION RISK & 0.222 & 0.416 & 0.000 & 0.000 & 0.000 \\
\hline INSTOWN & 0.367 & 0.343 & 0.000 & 0.303 & 0.698 \\
\hline GOVCUST & 0.107 & 0.309 & 0.000 & 0.000 & 0.000 \\
\hline DISTANCE2DC & 1.989 & 2.264 & 0.496 & 1.161 & 3.192 \\
\hline \multicolumn{6}{|c|}{ Panel B: Sample Means for Connected vs. Not Connected Observations } \\
\hline$\underline{\text { Variable }}^{\mathrm{a}}$ & $\begin{array}{r}C O N N \\
\quad(N=\end{array}$ & $9=1$ & $\begin{array}{r}\text { CONNEC } \\
(N=20\end{array}$ & $\begin{array}{l}=0 \\
5)\end{array}$ & $\begin{array}{l}\text { Difference }^{\mathrm{b}} \\
\text { (t-statistic) }\end{array}$ \\
\hline$\overline{G U I D E}$ & & & 0.2 & & $\begin{array}{c}0.250^{* * *} \\
(102.06)\end{array}$ \\
\hline POLICY WORDS & & & 0.1 & & $\begin{array}{l}0.174^{* * *} \\
(91.60)\end{array}$ \\
\hline HIGH POLICY WORDS & & & 0.0 & & $\begin{array}{l}0.060^{* * * *} \\
(74.73)\end{array}$ \\
\hline$S I Z E$ & & & 5.5 & & $\begin{array}{l}2.681^{* * *} \\
(262.47)\end{array}$ \\
\hline $\log (B T M)$ & & & -0.6 & & $\begin{array}{l}-0.113^{* * *} \\
(-23.23)\end{array}$ \\
\hline LOSS & & & 0.3 & & $\begin{array}{c}-0.191^{* * *} \\
(-76.01)\end{array}$ \\
\hline RETURN & & & 0.1 & & $\begin{array}{c}0.030^{* * * *} \\
(7.96)\end{array}$ \\
\hline RETVOL & & & 0.0 & & $\begin{array}{l}-0.013^{* * *} \\
(-107.21)\end{array}$ \\
\hline$L E V$ & & & 0.1 & & $\begin{array}{l}0.076^{* * *} \\
(68.58)\end{array}$ \\
\hline FOLLOWING & & & 4.2 & & $\begin{array}{c}6.883^{* * *} \\
(217.02)\end{array}$ \\
\hline LITIGATION RISK & & & 0.2 & & $\begin{array}{c}-0.093^{* * *} \\
(-41.11)\end{array}$ \\
\hline INSTOWN & & & 0.3 & & $\begin{array}{c}0.166^{* * *} \\
(90.59)\end{array}$ \\
\hline GOVCUST & & & 0.0 & & $\begin{array}{c}0.093^{* * *} \\
(55.79)\end{array}$ \\
\hline DISTANCE2DC & & & 2.0 & & $\begin{array}{c}-0.372^{* * *} \\
(-30.28)\end{array}$ \\
\hline
\end{tabular}




\begin{tabular}{|c|c|c|c|c|c|c|c|}
\hline \multicolumn{8}{|c|}{$\begin{array}{c}\text { TABLE 2 } \\
\text { Political Connections and Propensity to Guide }\end{array}$} \\
\hline Variable $^{\mathrm{a}, \mathrm{b}}$ & Prediction & (1) & (2) & (3) & (4) & (5) & (6) \\
\hline$\overline{C O N N E C T E D}$ & $(+)$ & $\mathbf{0 . 0 5}^{* * * *}$ & $\begin{array}{c}\mathbf{0 . 0 4} \\
(\mathbf{3 . 4 0})\end{array}$ & & & & \\
\hline CONNECTED $D_{\text {Candidate }}$ & $(+)$ & & & $\begin{array}{c}\mathbf{0 . 0 1 * * *} \\
(\mathbf{3 . 0 2})\end{array}$ & $\begin{array}{c}0.01 * * * \\
(2.69)\end{array}$ & & \\
\hline GOVAFFAIRS & $(+)$ & & & & & $\begin{array}{c}\mathbf{0 . 0 7} \\
(\mathbf{3 . 6 5})\end{array}$ & $\begin{array}{c}\mathbf{0 . 0 5}^{* * *} \\
(2.71)\end{array}$ \\
\hline SIZE & & $\begin{array}{c}0.01^{* * *} \\
(2.69)\end{array}$ & $\begin{array}{c}0.01^{* * *} \\
(4.71)\end{array}$ & $\begin{array}{c}0.01^{* *} \\
(2.47)\end{array}$ & $\begin{array}{c}0.01^{* * *} \\
(4.63)\end{array}$ & $\begin{array}{c}0.01^{* * * *} \\
(3.24)\end{array}$ & $\begin{array}{c}0.01^{* * *} \\
(5.58)\end{array}$ \\
\hline $\log (B T M)$ & & $\begin{array}{c}-0.02^{* * * *} \\
(-5.07)\end{array}$ & $\begin{array}{l}-0.00 \\
(-0.03)\end{array}$ & $\begin{array}{c}-0.02^{* * *} \\
(-5.14)\end{array}$ & $\begin{array}{l}-0.00 \\
(-0.03)\end{array}$ & $\begin{array}{c}-0.02^{* * * *} \\
(-4.81)\end{array}$ & $\begin{array}{r}0.00 \\
(0.24)\end{array}$ \\
\hline LOSS & & $\begin{array}{c}-0.06^{* * * *} \\
(-12.45)\end{array}$ & $\begin{array}{c}-0.06^{* * *} \\
(-13.79)\end{array}$ & $\begin{array}{c}-0.06^{* * *} \\
(-12.51)\end{array}$ & $\begin{array}{c}-0.06^{* * *} \\
(-13.82)\end{array}$ & $\begin{array}{c}-0.06^{* * *} \\
(-12.50)\end{array}$ & $\begin{array}{c}-0.06^{* * *} \\
(-13.71)\end{array}$ \\
\hline RETURN & & $\begin{array}{c}-0.01^{* * *} \\
(-5.05)\end{array}$ & $\begin{array}{c}-0.01^{* *} \\
(-2.52)\end{array}$ & $\begin{array}{c}-0.01^{* * *} \\
(-4.94)\end{array}$ & $\begin{array}{c}-0.01^{* *} \\
(-2.46)\end{array}$ & $\begin{array}{c}-0.01^{* * *} \\
(-5.11)\end{array}$ & $\begin{array}{c}-0.01^{* * *} \\
(-2.64)\end{array}$ \\
\hline$R O A$ & & $\begin{array}{c}0.19^{* * * *} \\
(11.51)\end{array}$ & $\begin{array}{c}0.12^{* * *} \\
(8.41)\end{array}$ & $\begin{array}{c}0.19^{* * * *} \\
(11.56)\end{array}$ & $\begin{array}{c}0.12^{* * * *} \\
(8.43)\end{array}$ & $\begin{array}{c}0.19^{* * * *} \\
(11.37)\end{array}$ & $\begin{array}{c}0.12^{* * * *} \\
(8.27)\end{array}$ \\
\hline RETVOL & & $\begin{array}{c}-0.62^{\text {**** }} \\
(-5.20)\end{array}$ & $\begin{array}{c}-0.97^{* * * *} \\
(-8.13)\end{array}$ & $\begin{array}{c}-0.64^{* * * *} \\
(-5.34)\end{array}$ & $\begin{array}{c}-0.98^{\text {**** }} \\
(-8.21)\end{array}$ & $\begin{array}{c}-0.64^{* * * *} \\
(-5.36)\end{array}$ & $\begin{array}{c}-0.96^{* * *} \\
(-8.04)\end{array}$ \\
\hline$L E V$ & & $\begin{array}{c}0.08^{* * * *} \\
(4.49)\end{array}$ & $\begin{array}{c}0.11^{* * * *} \\
(6.46)\end{array}$ & $\begin{array}{c}0.08^{* * * *} \\
(4.57)\end{array}$ & $\begin{array}{c}0.11^{* * * *} \\
(6.56)\end{array}$ & $\begin{array}{c}0.08^{* * * *} \\
(4.80)\end{array}$ & $\begin{array}{c}0.11^{* * * *} \\
(6.72)\end{array}$ \\
\hline INSTOWN & & $\begin{array}{c}0.15^{* * *} \\
(12.49)\end{array}$ & $\begin{array}{c}0.11^{* * *} \\
(9.87)\end{array}$ & $\begin{array}{c}0.15^{* * * *} \\
(12.56)\end{array}$ & $\begin{array}{c}0.11^{* * *} \\
(9.93)\end{array}$ & $\begin{array}{c}0.15^{* * *} \\
(12.49)\end{array}$ & $\begin{array}{c}0.11^{* * *} \\
(9.89)\end{array}$ \\
\hline $\log (F O L L O W I N G)$ & & $\begin{array}{c}0.13^{* * *} \\
(28.47)\end{array}$ & $\begin{array}{c}0.13^{* * *} \\
(29.53)\end{array}$ & $\begin{array}{l}0.13^{* * * *} \\
(28.71)\end{array}$ & $\begin{array}{c}0.13^{* * * *} \\
(29.75)\end{array}$ & $\begin{array}{l}0.13^{* * * *} \\
(28.97)\end{array}$ & $\begin{array}{l}0.13^{* * * *} \\
(29.96)\end{array}$ \\
\hline LITIGATION RISK & & $\begin{array}{c}0.06^{* * *} \\
(7.02)\end{array}$ & $\begin{array}{l}-0.00 \\
(-0.06)\end{array}$ & $\begin{array}{c}0.06^{* * * *} \\
(6.94)\end{array}$ & $\begin{array}{l}-0.00 \\
(-0.08)\end{array}$ & $\begin{array}{c}0.06^{* * * *} \\
(6.74)\end{array}$ & $\begin{array}{l}-0.00 \\
(-0.09)\end{array}$ \\
\hline Cluster by Firm & & Yes & Yes & Yes & Yes & Yes & Yes \\
\hline Year-Quarter Fixed Effects & & Yes & Yes & Yes & Yes & Yes & Yes \\
\hline Industry Fixed Effects & & No & Yes & No & Yes & No & Yes \\
\hline Adj. R-squared & & 0.21 & 0.27 & 0.21 & 0.27 & 0.21 & 0.27 \\
\hline $\mathrm{N}$ & & 248,614 & 248,614 & 248,614 & 248,614 & 248,614 & 248,614 \\
\hline
\end{tabular}

a All variables are defined in Appendix A.

${ }^{\mathrm{b}}$ All p-values are based on two-tailed tests (in parentheses) and are calculated based on standard errors that are clustered by firm. $*, * *, * * *$ indicate statistical significance at the $0.10,0.05$, and 0.01 levels (two-tailed test), respectively. 


\section{TABLE 3}

Political Connections and Propensity to Guide Conditional on Government Customers

\begin{tabular}{|c|c|c|c|c|c|c|c|}
\hline$\frac{\text { Variable }^{\mathrm{a}, \mathrm{b}}}{C O N N E C T E D}$ & $\frac{\text { Prediction }}{(+)}$ & $\begin{array}{l}\frac{(1)}{0.03^{*}} \\
(1.71)\end{array}$ & $\begin{array}{l}0.03^{* *} \\
(1.98)\end{array}$ & (3) & (4) & (5) & $\underline{(6)}$ \\
\hline CONNECTED $D_{\text {Candidate }}$ & $(+)$ & & & $\begin{array}{c}0.00 \\
(1.16)\end{array}$ & $\begin{array}{l}0.00 \\
(1.00)\end{array}$ & & \\
\hline GOVAFFAIRS & $(+)$ & & & & & $\begin{array}{c}0.04^{* *} \\
(2.09)\end{array}$ & $\begin{array}{c}0.02 \\
(1.11)\end{array}$ \\
\hline GOVCUST & & $\begin{array}{c}0.05^{* * *} \\
(4.41)\end{array}$ & $\begin{array}{l}0.01 \\
(0.65)\end{array}$ & $\begin{array}{c}0.05^{* * * *} \\
(4.29)\end{array}$ & $\begin{array}{l}0.00 \\
(0.40)\end{array}$ & $\begin{array}{c}0.07^{* * * *} \\
(6.00)\end{array}$ & $\begin{array}{l}0.02^{*} \\
(1.78)\end{array}$ \\
\hline CONNECTED $x$ GOVCUST & $(+)$ & $\begin{array}{c}\mathbf{0 . 0 8}^{* * * *} \\
(3.04)\end{array}$ & $\begin{array}{c}\mathbf{0 . 0 8}^{* * * *} \\
(3.06)\end{array}$ & & & & \\
\hline $\begin{array}{l}\text { CONNECTED } D_{\text {Candidate }} x \\
\text { GOVCUST }\end{array}$ & $(+)$ & & & $\begin{array}{c}\mathbf{0 . 0 2}^{* * * *} \\
(\mathbf{3 . 5 4})\end{array}$ & $\begin{array}{c}\mathbf{0 . 0 2} \\
(3.98)\end{array}$ & & \\
\hline GOVAFFAIRS $x$ GOVCUST & $(+)$ & & & & & $\begin{array}{c}\mathbf{0 . 1 2}^{* * * *} \\
(3.22)\end{array}$ & $\begin{array}{c}0.15^{* * * *} \\
(4.16)\end{array}$ \\
\hline Controls & & Yes & Yes & Yes & Yes & Yes & Yes \\
\hline Cluster by Firm & & Yes & Yes & Yes & Yes & Yes & Yes \\
\hline Year-Quarter Fixed Effects & & Yes & Yes & Yes & Yes & Yes & Yes \\
\hline Industry Fixed Effects & & No & Yes & No & Yes & No & Yes \\
\hline Adj. R-squared & & 0.21 & 0.27 & 0.21 & 0.27 & 0.21 & 0.27 \\
\hline $\mathrm{N}$ & & 248,614 & 248,614 & 248,614 & 248,614 & 248,614 & 248,614 \\
\hline $\begin{array}{l}\text { F Statistic: CONNECTED + } \\
\text { CONNECTED } x \text { GOVCUST }\end{array}$ & & $17.76^{* * *}$ & $17.83^{* * *}$ & $21.05^{* * *}$ & $23.28^{* * *}$ & $22.39^{* * *}$ & $25.63^{* * *}$ \\
\hline
\end{tabular}

${ }^{\text {a }}$ All variables are defined in Appendix A.

${ }^{\mathrm{b}}$ All p-values are based on two-tailed tests (in parentheses) and are calculated based on standard errors that are clustered by firm.

$*, * *, * * *$ indicate statistical significance at the $0.10,0.05$, and 0.01 levels (two-tailed test), respectively. 
TABLE 4

Political Connections and Policy Word Use Within Guidance

\begin{tabular}{|c|c|c|c|c|c|c|c|}
\hline \multirow[b]{2}{*}{$\frac{\text { Variable }^{\mathrm{a}, \mathrm{b}}}{C O N N E C T E D}$} & \multirow[b]{2}{*}{$\frac{\text { Prediction }}{(+)}$} & \multicolumn{3}{|c|}{$\underline{\text { HIGH POLICY WORDS }}$} & \multicolumn{3}{|c|}{$\underline{P O L I C Y \text { WORDS }}$} \\
\hline & & $\begin{array}{c}\mathbf{( 1 )}_{(\mathbf{0 3}}^{* * * *} \\
(4.97)\end{array}$ & $\underline{(2)}$ & $\underline{(3)}$ & $\begin{array}{c}\frac{(4)}{0.03}{ }^{* * *} \\
(2.60)\end{array}$ & $\underline{(5)}$ & $\underline{(6)}$ \\
\hline $\log \left(C O N N E C T E D_{\text {Candidate }}\right)$ & $(+)$ & & $\begin{array}{c}\mathbf{0 . 0 1}^{* * * *} \\
(\mathbf{5 . 4 6 )}\end{array}$ & & & $\begin{array}{c}\mathbf{0 . 0 1}^{* * * *} \\
(3.56)\end{array}$ & \\
\hline GOVAFFAIRS & $(+)$ & & & $\begin{array}{c}0.07^{* * * *} \\
(5.39)\end{array}$ & & & $\begin{array}{c}0.06 \text { *** } \\
(4.00)\end{array}$ \\
\hline SIZE & & $\begin{array}{c}0.02^{* * *} \\
(7.51)\end{array}$ & $\begin{array}{c}0.02^{* * *} \\
(6.50)\end{array}$ & $\begin{array}{c}0.02^{* * * *} \\
(7.68)\end{array}$ & $\begin{array}{c}-0.01^{* *} \\
(-2.25)\end{array}$ & $\begin{array}{c}-0.01^{\text {**** }} \\
(-3.05)\end{array}$ & $\begin{array}{c}-0.01^{* *} \\
(-2.52)\end{array}$ \\
\hline $\log (B T M)$ & & $\begin{array}{c}0.01^{* * *} \\
(4.48)\end{array}$ & $\begin{array}{c}0.01^{* * *} \\
(3.98)\end{array}$ & $\begin{array}{c}0.01^{* * * *} \\
(4.47)\end{array}$ & $\begin{array}{c}-0.01^{* *} \\
(-2.21)\end{array}$ & $\begin{array}{c}-0.01^{* *} \\
(-2.49)\end{array}$ & $\begin{array}{c}-0.01^{* *} \\
(-2.24)\end{array}$ \\
\hline LOSS & & $\begin{array}{c}0.01^{* * * *} \\
(5.38)\end{array}$ & $\begin{array}{c}0.01^{* * * *} \\
(5.15)\end{array}$ & $\begin{array}{c}0.02^{* * * *} \\
(5.46)\end{array}$ & $\begin{array}{c}-0.02^{* * * *} \\
(-3.39)\end{array}$ & $\begin{array}{c}-0.02^{* * * *} \\
(-3.53)\end{array}$ & $\begin{array}{c}-0.02^{* * *} \\
(-3.35)\end{array}$ \\
\hline RETURN & & $\begin{array}{l}0.00^{*} \\
(1.78)\end{array}$ & $\begin{array}{l}0.00^{* *} \\
(2.21)\end{array}$ & $\begin{array}{l}0.00^{*} \\
(1.70)\end{array}$ & $\begin{array}{c}-0.02^{* * * *} \\
(-4.28)\end{array}$ & $\begin{array}{c}-0.02^{* * * *} \\
(-4.10)\end{array}$ & $\begin{array}{r}-0.02^{* * *} \\
(-4.31)\end{array}$ \\
\hline$R O A$ & & $\begin{array}{c}-0.03^{* *} \\
(-2.16)\end{array}$ & $\begin{array}{l}-0.03^{*} \\
(-1.94)\end{array}$ & $\begin{array}{l}-0.03^{* *} \\
(-2.05)\end{array}$ & $\begin{array}{c}0.09^{* * *} \\
(3.06)\end{array}$ & $\begin{array}{c}0.10^{* * * *} \\
(3.15)\end{array}$ & $\begin{array}{c}0.10^{* * *} \\
(3.09)\end{array}$ \\
\hline RETVOL & & $\begin{array}{c}0.75^{* * *} \\
(5.56)\end{array}$ & $\begin{array}{c}0.71^{* * *} \\
(5.43)\end{array}$ & $\begin{array}{c}0.68^{* * * *} \\
(5.13)\end{array}$ & $\begin{array}{c}-0.93^{* * *} \\
(-3.47)\end{array}$ & $\begin{array}{c}-0.96^{* * *} \\
(-3.60)\end{array}$ & $\begin{array}{c}-0.98^{* * *} \\
(-3.67)\end{array}$ \\
\hline$L E V$ & & $\begin{array}{c}0.03^{* * * *} \\
(2.81)\end{array}$ & $\begin{array}{c}0.03^{* * *} \\
(2.74)\end{array}$ & $\begin{array}{c}0.04^{* * * *} \\
(3.38)\end{array}$ & $\begin{array}{c}-0.10^{* * * *} \\
(-4.53)\end{array}$ & $\begin{array}{c}-0.10^{* * * *} \\
(-4.57)\end{array}$ & $\begin{array}{c}-0.09^{* * *} \\
(-4.29)\end{array}$ \\
\hline INSTOWN & & $\begin{array}{l}0.00 \\
(0.68)\end{array}$ & $\begin{array}{l}0.00 \\
(0.78)\end{array}$ & $\begin{array}{c}0.00 \\
(0.58)\end{array}$ & $\begin{array}{c}0.13^{* * *} \\
(10.85)\end{array}$ & $\begin{array}{l}0.13^{* * * *} \\
(10.91)\end{array}$ & $\begin{array}{c}0.13^{* * *} \\
(10.86)\end{array}$ \\
\hline $\log (F O L L O W I N G)$ & & $\begin{array}{c}-0.01^{* *} \\
(-2.15)\end{array}$ & $\begin{array}{l}-0.01 \\
(-1.62)\end{array}$ & $\begin{array}{l}-0.01^{*} \\
(-1.78)\end{array}$ & $\begin{array}{c}0.03^{* * *} \\
(3.79)\end{array}$ & $\begin{array}{c}0.03^{* * *} \\
(4.02)\end{array}$ & $\begin{array}{c}0.03^{* * *} \\
(3.94)\end{array}$ \\
\hline LITIGATION RISK & & $\begin{array}{l}-0.00 \\
(-0.55)\end{array}$ & $\begin{array}{l}-0.00 \\
(-0.46)\end{array}$ & $\begin{array}{l}-0.00 \\
(-0.23)\end{array}$ & $\begin{array}{l}-0.00 \\
(-0.24)\end{array}$ & $\begin{array}{l}-0.00 \\
(-0.21)\end{array}$ & $\begin{array}{l}-0.00 \\
(-0.13)\end{array}$ \\
\hline Cluster by Firm & & Yes & Yes & Yes & Yes & Yes & Yes \\
\hline Year-Quarter Fixed Effects & & Yes & Yes & Yes & Yes & Yes & Yes \\
\hline Industry Fixed Effects & & Yes & Yes & Yes & Yes & Yes & Yes \\
\hline Adj. R-squared & & 0.07 & 0.07 & 0.07 & 0.21 & 0.21 & 0.21 \\
\hline $\mathrm{N}$ & & 75,076 & 75,076 & 75,076 & 75,076 & 75,076 & 75,076 \\
\hline
\end{tabular}

a All variables are defined in Appendix A.

${ }^{\mathrm{b}}$ All p-values are based on two-tailed tests (in parentheses) and are calculated based on standard errors that are clustered by firm.

$*, * *, * * *$ indicate statistical significance at the $0.10,0.05$, and 0.01 levels (two-tailed test), respectively. 


\begin{tabular}{|c|c|c|c|c|}
\hline \multicolumn{5}{|c|}{$\begin{array}{l}\text { TABLE } 5 \\
\text { Political Connections and Propensity to Guide - Entropy Balanced Sample }\end{array}$} \\
\hline$\frac{\text { Variable }^{\mathrm{a}, \mathrm{b}}}{C O N N E C T E D}$ & $\begin{array}{c}\frac{(1)}{0.08^{* * *}} \\
(4.99)\end{array}$ & $\frac{(2)}{\mathbf{0 . 0 6}^{* * *}}$ & (3) & $\underline{(4)}$ \\
\hline GOVAFFAIRS & & & $\begin{array}{c}\mathbf{0 . 1 4} 4^{* * *} \\
(7.04)\end{array}$ & $\begin{array}{c}\mathbf{0 . 0 5}^{* * *} \\
(\mathbf{3 . 0 8})\end{array}$ \\
\hline SIZE & $\begin{array}{c}-0.03^{* * *} \\
(-5.79)\end{array}$ & $\begin{array}{c}-0.01^{* * *} \\
(-2.63)\end{array}$ & $\begin{array}{c}-0.06^{* * *} \\
(-8.53)\end{array}$ & $\begin{array}{c}-0.03^{* * *} \\
(-4.20)\end{array}$ \\
\hline $\log (B T M)$ & $\begin{array}{c}-0.09^{* * *} \\
(-8.36)\end{array}$ & $\begin{array}{l}-0.02^{* *} \\
(-2.33)\end{array}$ & $\begin{array}{c}-0.09^{* * *} \\
(-6.29)\end{array}$ & $\begin{array}{l}-0.02 \\
(-1.63)\end{array}$ \\
\hline LOSS & $\begin{array}{c}-0.06^{* * *} \\
(-6.30)\end{array}$ & $\begin{array}{c}-0.07^{* * *} \\
(-7.70)\end{array}$ & $\begin{array}{c}-0.08^{* * *} \\
(-5.83)\end{array}$ & $\begin{array}{c}-0.08^{* * * *} \\
(-6.36)\end{array}$ \\
\hline RETURN & $\begin{array}{c}-0.03^{* * *} \\
(-5.01)\end{array}$ & $\begin{array}{l}-0.01^{* *} \\
(-2.33)\end{array}$ & $\begin{array}{c}-0.05^{* * *} \\
(-4.26)\end{array}$ & $\begin{array}{c}-0.02^{* *} \\
(-1.96)\end{array}$ \\
\hline$R O A$ & $\begin{array}{l}0.04 \\
(0.51)\end{array}$ & $\begin{array}{l}0.07 \\
(0.98)\end{array}$ & $\begin{array}{l}0.14 \\
(0.94)\end{array}$ & $\begin{array}{l}0.11 \\
(0.91)\end{array}$ \\
\hline RETVOL & $\begin{array}{c}-5.56^{* * *} \\
(-11.24)\end{array}$ & $\begin{array}{c}-3.78^{* * *} \\
(-9.06)\end{array}$ & $\begin{array}{c}-10.28^{* * *} \\
(-11.97)\end{array}$ & $\begin{array}{c}-6.02^{* * *} \\
(-8.84)\end{array}$ \\
\hline$L E V$ & $\begin{array}{c}0.10^{* *} \\
(2.27)\end{array}$ & $\begin{array}{c}0.15^{* * * *} \\
(3.59)\end{array}$ & $\begin{array}{c}0.14^{* *} \\
(2.42)\end{array}$ & $\begin{array}{c}0.24^{* * *} \\
(4.74)\end{array}$ \\
\hline INSTOWN & $\begin{array}{c}0.15^{* * *} \\
(7.23)\end{array}$ & $\begin{array}{c}0.11^{* * * *} \\
(5.98)\end{array}$ & $\begin{array}{c}0.16^{* * * *} \\
(5.17)\end{array}$ & $\begin{array}{c}0.13^{* * *} \\
(5.07)\end{array}$ \\
\hline $\log (F O L L O W I N G)$ & $\begin{array}{c}0.09^{* * *} \\
(10.20)\end{array}$ & $\begin{array}{l}0.10^{* * * *} \\
(12.40)\end{array}$ & $\begin{array}{c}0.10^{* * * *} \\
(7.49)\end{array}$ & $\begin{array}{c}0.11^{* * *} \\
(9.33)\end{array}$ \\
\hline LITIGATION RISK & $\begin{array}{c}0.14^{* * * *} \\
(6.34)\end{array}$ & $\begin{array}{l}-0.06 \\
(-1.56)\end{array}$ & $\begin{array}{c}0.14^{* * *} \\
(4.76)\end{array}$ & $\begin{array}{c}-0.14^{* * * *} \\
(-2.92)\end{array}$ \\
\hline Cluster by Firm & Yes & Yes & Yes & Yes \\
\hline Year-Quarter Fixed Effects & Yes & Yes & Yes & Yes \\
\hline Industry Fixed Effects & No & Yes & No & Yes \\
\hline Adj. R-squared & 0.11 & 0.23 & 0.14 & 0.29 \\
\hline $\mathrm{N}$ & 248,614 & 248,614 & 248,614 & 248,614 \\
\hline
\end{tabular}

a All variables are defined in Appendix A.

${ }^{\mathrm{b}}$ All p-values are based on two-tailed tests (in parentheses) and are calculated based on standard errors that are clustered by firm.

$*^{* * * * * *}$ indicate statistical significance at the $0.10,0.05$, and 0.01 levels (two-tailed test), respectively. 


\begin{tabular}{|c|c|c|c|c|c|c|c|}
\hline \multicolumn{8}{|c|}{$\begin{array}{l}\text { TABLE } 6 \\
\text { ons and Propensity to Guide - Instrumental Variable }\end{array}$} \\
\hline & \multirow[b]{2}{*}{$\underline{\text { Prediction }}$} & \multicolumn{2}{|c|}{ CONNECTED } & \multicolumn{2}{|c|}{$\underline{\text { CONNECTED }}{ }_{\text {Candidate }}$} & \multicolumn{2}{|c|}{ GOVAFFAIRS } \\
\hline Variable $^{\mathrm{a}, \mathrm{b}}$ & & $\frac{1^{\text {st }} \text { Stage }}{(1)}$ & $\frac{2^{\text {nd }} \text { Stage }}{(2)}$ & $\frac{1^{\text {st }} \text { Stage }}{(3)}$ & $\frac{2^{\text {nd }} \text { Stage }}{(4)}$ & $\frac{1^{\text {st }} \text { Stage }}{(5)}$ & $\frac{2^{\text {nd }} \text { Stage }}{(6)}$ \\
\hline$\overline{C O N N E C T E D}$ & $(+)$ & $\longrightarrow$ & $\begin{array}{c}\mathbf{0 . 3 7} \\
(\mathbf{3 . 2 5})\end{array}$ & & & & \\
\hline CONNECTED $D_{\text {Candidate }}$ & $(+)$ & & & & $\begin{array}{c}\mathbf{0 . 0 8}^{* * *} \\
(\mathbf{3 . 2 8})\end{array}$ & & \\
\hline GOVAFFAIRS & $(+)$ & & & & & & $\begin{array}{c}0.73^{* * *} \\
(3.19)\end{array}$ \\
\hline DISTANCE2DC & $(-)$ & $\begin{array}{c}-0.01^{* * *} \\
(-8.69)\end{array}$ & & $\begin{array}{c}-0.06^{* * *} \\
(-9.90)\end{array}$ & & $\begin{array}{c}-0.01^{* * *} \\
(-8.49)\end{array}$ & \\
\hline Wald $X^{2}$ & & 2,0 & $2^{* * *}$ & 2,8 & $1^{* * *}$ & 1,2 & $*^{* * *}$ \\
\hline Controls & & & & & & & \\
\hline Cluster by Firm & & & & & & & \\
\hline Year-Qtr. Fixed Effects & & & & & & & \\
\hline Industry Fixed Effects & & & & & & & \\
\hline $\mathrm{N}$ & & & & & & & \\
\hline
\end{tabular}

a All variables are defined in Appendix A.

${ }^{\mathrm{b}}$ All p-values are based on two-tailed tests (in parentheses) and are calculated based on standard errors that are clustered by firm.

$*, * *, * * *$ indicate statistical significance at the $0.10,0.05$, and 0.01 levels (two-tailed test), respectively. 


\section{TABLE 7}

\begin{tabular}{|c|c|c|c|c|}
\hline \multicolumn{5}{|c|}{ Political Connections and Propensity to Guide - Robustness } \\
\hline \multicolumn{5}{|c|}{ Panel A: Firm Fixed Effects } \\
\hline$\frac{\text { Variable }^{\mathrm{a}, \mathrm{b}}}{C O N N E C T E D}$ & $\frac{\text { Prediction }}{(+)}$ & $\begin{array}{l}\frac{(1)}{(2.03} * * \\
(2.07)\end{array}$ & $\underline{(2)}$ & (3) \\
\hline CONNECTED $D_{\text {Candidate }}$ & $(+)$ & & $\begin{array}{l}\text { 0.01* } \\
(\mathbf{1 . 7 0})\end{array}$ & \\
\hline GOVAFFAIRS & $(+)$ & & & $\begin{array}{l}-0.00 \\
(-0.23)\end{array}$ \\
\hline Controls & & Yes & Yes & Yes \\
\hline Cluster by Firm & & Yes & Yes & Yes \\
\hline Year-Quarter Fixed Effects & & Yes & Yes & Yes \\
\hline Firm Fixed Effects & & Yes & Yes & Yes \\
\hline Adj. R-squared & & 0.60 & 0.60 & 0.60 \\
\hline $\mathrm{N}$ & & 248,614 & 248,614 & 248,614 \\
\hline \multicolumn{5}{|c|}{ Panel B: Sensitivity to Economic Policy Uncertainty } \\
\hline$\frac{\text { Variable }^{\mathrm{a}, \mathrm{b}}}{\text { CONNECTED }}$ & $\frac{\text { Prediction }}{(+)}$ & $\frac{(1)}{0.04^{* * *}}$ & $(2)$ & (3) \\
\hline CONNECTED $D_{\text {Candidate }}$ & $(+)$ & & $\begin{array}{l}0.01^{* *} \\
(2.26)\end{array}$ & \\
\hline GOVAFFAIRS & $(+)$ & & & $\begin{array}{c}0.066^{* * *} \\
(3.11)\end{array}$ \\
\hline EPU BETA & & $\begin{array}{l}0.00^{* * *} \\
(2.43)\end{array}$ & $\begin{array}{l}0.00^{\text {*** }} \\
(2.40)\end{array}$ & $\begin{array}{l}0.00^{* *} \\
(2.41)\end{array}$ \\
\hline Controls & & Yes & Yes & Yes \\
\hline Cluster by Firm & & Yes & Yes & Yes \\
\hline Year-Quarter Fixed Effects & & Yes & Yes & Yes \\
\hline Industry Fixed Effects & & Yes & Yes & Yes \\
\hline Adj. R-squared & & 0.27 & 0.27 & 0.27 \\
\hline $\mathrm{N}$ & & 228,500 & 228,500 & 228,500 \\
\hline
\end{tabular}

${ }^{a}$ All variables are defined in Appendix A.

${ }^{\mathrm{b}}$ All p-values are based on two-tailed tests (in parentheses) and are calculated based on standard errors that are clustered by firm. $*, * *, * * *$ indicate statistical significance at the $0.10,0.05$, and 0.01 levels (two-tailed test), respectively. 


\begin{tabular}{|c|c|c|c|c|}
\hline \multicolumn{5}{|c|}{$\begin{array}{c}\text { TABLE 8 } \\
\text { Guidance Around Final Roll-Call Vote }\end{array}$} \\
\hline \multicolumn{5}{|c|}{ Panel A: Kolmogorov-Smirnov Two-Sample Test for Distribution Around Final Roll-Call Vote } \\
\hline Null Hypothesis & \multicolumn{2}{|c|}{30 Days Pre } & \multicolumn{2}{|c|}{30 Days Post } \\
\hline Not Connected > Connected & \multicolumn{2}{|c|}{$\leq 0.001$} & \multicolumn{2}{|c|}{0.959} \\
\hline Not Connected < Connected & \multicolumn{2}{|c|}{$\geq 0.999$} & \multicolumn{2}{|c|}{0.009} \\
\hline Not Connected $=$ Connected & \multicolumn{2}{|c|}{$\leq 0.001$} & \multicolumn{2}{|c|}{0.019} \\
\hline \multicolumn{5}{|c|}{ Panel B: Epps-Singleton Two-Sample Test for Distribution Around Final Roll-Call Vote } \\
\hline Null Hypothesis & \multicolumn{2}{|c|}{30 Days Pre } & \multicolumn{2}{|c|}{ 30 Days Post } \\
\hline Not Connected $=$ Connected & \multicolumn{2}{|c|}{0.003} & \multicolumn{2}{|c|}{0.085} \\
\hline \multicolumn{5}{|c|}{ Panel C: Regression Analyses of Days from Final Roll-Call Vote to Guidance Release } \\
\hline Variable $^{\mathrm{a}, \mathrm{b}}$ & Prediction & $(1)$ & Prediction & $(2)$ \\
\hline$\overline{C O N N E C T E D}$ & $(-)$ & $\begin{array}{l}-2.16 \\
(-2.46)\end{array}$ & $(-)$ & $\begin{array}{c}-2.58 \\
(-2.82)\end{array}$ \\
\hline FAST & & & $(-)$ & $\begin{array}{c}-1.23^{* * *} \\
(-2.68)\end{array}$ \\
\hline CONNECTED $x$ FAST & & & $(+)$ & $\begin{array}{c}1.64^{* * *} \\
(2.59)\end{array}$ \\
\hline Controls & & Yes & & Yes \\
\hline Cluster by Firm & & Yes & & Yes \\
\hline Year-Quarter Fixed Effects & & Yes & & Yes \\
\hline Calendar Month Fixed Effects & & Yes & & Yes \\
\hline Firm Fixed Effects & & Yes & & Yes \\
\hline Adj. R-squared & & 0.14 & & 0.14 \\
\hline $\mathrm{N}$ & & 49,394 & & 49,394 \\
\hline $\begin{array}{l}\text { F Statistic: CONNECTED + } \\
\text { CONNECTED } \times \text { FAST }=0\end{array}$ & & & & 0.98 \\
\hline \multicolumn{5}{|c|}{ Panel D: Textual Differences Between Guidance Issued Prior to Bill Introduction and Passage } \\
\hline$\underline{\text { Variable }^{\mathrm{a}, \mathrm{b}}}$ & Prediction & & $(1)$ & \\
\hline$\overline{C O N N E C T E D}$ & $(+)$ & & $\begin{array}{r}\mathbf{0 . 0 6}{ }^{* * *} \\
(3.43)\end{array}$ & \\
\hline Controls & & & Yes & \\
\hline Cluster by Firm & & & Yes & \\
\hline Year-Quarter Fixed Effects & & & Yes & \\
\hline Industry Fixed Effects & & & Yes & \\
\hline Adj. R-squared & & & 0.14 & \\
\hline $\mathrm{N}$ & & & 5,522 & \\
\hline
\end{tabular}

a All variables are defined in Appendix A.

${ }^{\mathrm{b}}$ All p-values are based on two-tailed tests (in parentheses) and are calculated based on standard errors that are clustered by firm.

$*, * *, * * *$ indicate statistical significance at the $0.10,0.05$, and 0.01 levels (two-tailed test), respectively. 